\title{
Multi-level qualification of Parafluvial Exchange within the Hyporheic Zone Affected by River Sinuosity and Seasonal Change using Multi-tracer Methods.
}

\author{
Amin reza Meghdadi ${ }^{1}$, Morteza Eyvazi $^{2}$ \\ ${ }^{1}$ School of Earth, Environmental and Biological Science, Queensland University of Technology, Brisbane, Qld \\ 4000, Australia
}

${ }^{2}$ Department of Agriculture and Plant Breeding, Faculty of Agriculture, Zanjan University, Zanjan, Iran

Correspondence to: Amin reza Meghdadi (a.meghdadi@qut.edu.au)

Abstract. Exchange of water in the parafluvial zone, located along the boundaries of meandering streams, arises methods for qualitative scrutiny of losing (recharge) or gaining (discharge) reaches along the parafluvial zone. Hence, the main objective of this study is to qualitatively characterize the spatio-temporal alteration in parafluvial exchange within the hyporheic zone (PEHZ) by simultaneous application of multi-tracer methods. For this approach, first, Hierarchical Cluster Analysis (HCA) in conjunction with groundwater hydrochemistry analysis was used to evaluate the representativeness of parafluvial assessment network. Then, water stable isotope compositions $\left(\delta^{18} \mathrm{O}\right.$ and $\left.\delta^{2} \mathrm{H}\right)$, radioisotope $\left({ }^{222} \mathrm{Rn}\right)$, and environmental tracers (Temperature and EC) were measured at multiple depths $(20 \mathrm{~cm}$ to $100 \mathrm{~cm}$ depths below streambed) during the wet and dry season to qualitatively elucidate the PEHZ in the Ghezel-Ozan River, a third order river located in the northwest of Iran. By groundwater hydrochemistry assessment identified, $\mathrm{NaHCO}_{3}$ and $\mathrm{CaHCO}_{3}$ as the dominant water type in dry and wet season, respectively. Moreover, the HCA approach designed two different clusters for each season for accurate interpretation of PEHZ. Results obtained from stable isotope and environmental tracer analysis of bore water, surface water, and parafluvial water distinguished stream-aquifer connectivity with highly seasonal and spatial variations. In the dry season, for example, $\delta^{18} \mathrm{O}, \delta^{2} \mathrm{H}$, and EC varied from -3.59 to -1.88 (\%o VSMOW), 31.08 to -24.06 (\%o VSMOW), and 234 to $740.65 \mu \mathrm{S} / \mathrm{cm}$ respectively. Also, the results acquired from the integration of $\delta^{18} \mathrm{O}$ and EC revealed complex spatio-temporal stream-aquifer connectivity (PEHZ). In low flow conditions, groundwater outflow mainly occurred at $100 \mathrm{~cm}$ depth while the dominance of groundwater outflow 
at $20 \mathrm{~cm}$ depth prevailed during high flow conditions. The continuous and point scale measurements of temperature and ${ }^{222} \mathrm{Rn}$ were highly in accordance with the results of $\delta^{18} \mathrm{O}$ and EC. Furthermore, diel temperature fluctuation, as well as radon activity variations at multi-level scale, expressed the PEHZ (especially at depth greater than 60 $\mathrm{cm})$ are affected by large-scale regional flow-field which is embedded within. The synthesized approaches used in this study provide a useful insight into the spatiotemporal changes of stream-aquifer connectivity which make the more efficient monitoring and interpretation of hydrological processes possible. They can be, furthermore, utilized to pinpoint the losing/gaining reaches accurately to tackle environmental problems such as monitoring the transport of anthropogenic contaminants in a system.

Keywords: Parafluvial exchange, river sinuosity, HCA, multi-tracer method, gaining stream, losing stream,

\section{Introduction}

Groundwater is part of the water cycle and is a major contributor to surface water (Ben-zvi-Assarf and Orion, 2005; Winter, 1998). The exchange of water between groundwater and surface water typically occurs in the saturated interatrial area beneath and adjacent to the stream bed, which is called the hyporheic zone (Boulton et al., 1998; Findlay, 1995). Exchange of solutes between the river and hyporheic zone influences the biology and hydrochemistry of the stream and aquifer. However, due to its dynamic physio-geochemical and boundary condition, the hyporheic zone is one of the most challenging areas to investigate (Cardenas et al., 2004; Zarnetske et al., 2008). Therefore, the characterisation of groundwater exchange within the hyporheic zone, especially at different depths, and its effect on the transport and fate of water and dissolved nutrients plays a vital role in environmental management (Smith et al., 2008).

Hyporheic exchange zones are widely accepted as physio-geochemical hotspots in the river and aquifer systems. For instance, hyporheic exchange is responsible for the discharge of anthropogenic contaminants such as nitrate into streams. The discharge rate and the fate of anthropogenic contaminants are mainly affected by the biogeochemical composition, volume, and residence time within the exchange zone.

Hyporheic exchange, depending on the scale, can be governed by riffle-pool sequences (Gariglio et al., 2013; Naranjo et al., 2013; Storey et al., 2003; Tonina and Buffington, 2007), stream morphology (Buffington and Tonina, 2009; Wondzell, 2006; Zarnetske et al., 2008), and stream curvature or sinuosity (Gu et al., 2016; Zhang et al., 2017). Stream curvature is of great importance in high order streams where stream meanders influence the creation of a parafluvial zone, a region of bank-full channel boundaries located within the boundaries of the 
sinuous stream. Hyporheic exchange is accentuated in the intra-meander region, in this setting, the parafluvial zone raises the hyporheic flow fields where the predominant river patterns like biogeochemical zonation are dictated (Briody et al., 2016; Cook, 2013; Malard et al., 2002). However, it is evident that parafluvial exchange is affected by rivers' physical and hydrological features, but the effect of seasonal change or distinctive flow conditions on upward movement (i.e. parafluvial sediments are the source of contaminants) or downward movement (parafluvial sediments are sink of contaminants) are an areas of active research (Hester et al., 2017).

This problem is aggravated when we deal with geochemical changes at multi-level scale within the hyporheic zone (Zhu et al., 2015). Accordingly, combining multiple evaluation techniques to characterize parafluvial exchange within the hyporheic zone (PEHZ) at different levels and dynamic flow conditions could be a practical and efficient solution to tackle this quandary.

A large number of methods have been proposed to characterize groundwater-surface water exchange qualitatively. One of the most widely used methods is based on hydraulic gradient analysis (Veras et al., 2016; Wang et al., 2016; Welch et al., 2015). This method is not an adequate means to estimate mixing dynamics of groundwater in the hyporheic zone, since shifting and fluctuating characteristics of the boundary conditions in the parafluvial zone are due to changes in river stage in different flood events. This fluctuation in the river stage causes high spatio-temporal variation of the hydraulic parameters, which makes it unsuitable to use in a parafluvial zone within a hyporheic area.

Recently naturally occurring environmental tracers like Radio Isotope ${ }^{222} \mathrm{Rn}$ (Burnett et al., 2010b; Cartwright et al., 2011; Peterson et al., 2010), temperature (Hatch et al., 2006; Keery et al., 2007; Lee, 1977; Sophocleous, 2002), electrical conductivity (Harvey et al., 1997) and stable isotopes of Deuterium (D) and oxygen-18 $\left({ }^{18} \mathrm{O}\right)$ (Arnoux et al., 2017; Rugel et al., 2016) have proven to be cost-effective, efficient, and widely applied means to deal with groundwater-surface water interaction. Temperature is a widely used environmental tracer to appraise groundwater-surface water interaction because of its usefulness to define the small-scale flowpaths like sand bar or stream bed flow paths (Stonestrom and Constantz, 2003). Also, temperature depth profile in combination with piezometric head data was employed by Hyun et al. (2011) to study seepage flux in agricultural lands. The result of the study was supported by EC data that enabled them to precisely delineate where surface water-groundwater mixing occurs. Following the above studies, it could be concluded that temperature and EC are useful to characterize stream-aquifer connectivity (gaining, losing, and neutral). However, there is disagreement among researchers about the potential of temperature to characterize hyporheic flow in comparison with EC potential. 
interaction. Even though they noted that the results of both tracers are consistent with each other, temperature has been found to be less sensitive than EC for groundwater hydrogeological characterization.

Another tracer that is beginning to be more widely used to identify locations of groundwater discharge to rivers is radio-isotope radon (Burnett et al., 2010b; Cartwright et al., 2011; Peterson et al., 2010). It has been used as a tracer of groundwater discharge to rivers in studies from Puerto Rico (Ellins et al., 1990), USA (Genereux et al., 1993; Lee and Hollyday, 1993), Japan (Yoneda et al., 1991), and Australia (Cook et al., 2003). Stable isotopes (e.g. D and ${ }^{18} \mathrm{O}$ ) have been used to discretize hyporheic flow (Vanplantinga et al., 2017). In addition, the stable isotopes, specifically $\mathrm{D}$ and ${ }^{18} \mathrm{O}$, are precise indicators to quantify the contribution of active and permafrost layers to surface water hydrology (McLean et al., 1999; Throckmorton et al., 2016).

10 These tracers were mostly applied independently and at a depth scale, as only a few studies have applied simultaneous application of these tracers at different depth (Hermans et al., 2015; Lapworth et al., 2015). On the other hand, several authors have demonstrated the necessity and appropriateness of the simultaneous use of several traces at multi-level scale to achieve a practical level of knowledge on the at depth hyporheic exchange and flux transport. The advantage of the concurrent implementation of several environmental tracer methods has been demonstrated by Brodie et al. (2007), As proper results can be obtained by simultaneous application of complimentary tracer methods (Andersen and Acworth, 2009; Burnett et al., 2010a; Kalbus et al., 2006; Stellato et al., 2008). Also, to deal with the discrepancy in tracer results, Anderson (2005) and Unland et al. (2013) proposed the integration of isotope tracer and geochemical tracer techniques. While combining the techniques like stable isotopes and natural tracers not only brings about more precise outcomes, it also makes an appropriate and concrete characterization of the hydrogeological relationship between surface water and hyporheic compartments possible.

However, comparative studies which evaluate the applicability of different environmental traces with respect to the particular properties of the parafluvial zones within the hyporheic area are still rare (Engelhardt et al., 2011). Unland et al. (2013) and Cox et al. (2007) pointed out that, due to the heterogeneity and various scale effects of the parafluvial zone and the analytical uncertainties associated with the high discrepancies of computational trace elements in surface water compared to groundwater, determining the hyporheic exchange in meandering areas remains a challenge.

Hence, the main objective of this study is to characterize the spatio-temporal variation and the governing patterns of PEHZ ,by simultaneous application of Electrical Conductivity (EC), Temperature (T), ${ }^{222} \mathrm{Rn}$, as well as ${ }^{18} \mathrm{O}$ - 
D, and water hydrochemistry in the parafluvial zone within the hyporheic area of the Ghezel-Ozan River, a third order river in the north-west of Iran. Also, the change in hyporheic flux in response to seasonal variation in the river discharge (low flow and high flow conditions) will be assessed by the combined application of EC and $\delta 18 \mathrm{O}$, and the transition from losing to gaining condition at point scale will be discerned through the high flow and low flow seasons. The validity and applicability of the integrated techniques to qualify the spatial patterns and temporal dynamics of PEHZ at different depths will be scrutinized. The integration of the proposed techniques (EC and $\delta 18 \mathrm{O}$ ) is based on i) the suitability of selected tracers to assess the parafluvial exchange, ii) their inverse function on the hyporheic zone and SW, and iii) their mutual non-interaction in a system. Employing multiple techniques for such an investigation and at different depths not only leads to a better understanding of the biogeochemical reaction in the hyporheic zone feasible, but is also so crucial to pinpoint the fluxes of the anthropogenic contaminants, such as nitrate, prior to their discharge into streams (Oyarzún et al., 2014).

\section{Study area}

The Ghezel-Ozan River is located in the northwest of Iran (Figure 1) and is approximately $800 \mathrm{~km}$ long. It is impounded by the Manjil dam and is the primary water source of about $3 \mathrm{M}$ people from three different provinces.

The river receives approximately $1523 \mathrm{~mm}$ of annual precipitation (Dodangeh et al., 2014) and is extremely seasonal. The mean flow ranges from $2.54 \mathrm{~m}^{3} \mathrm{~s}$ in the dry season (July-September) to a mean flow of $31.75 \mathrm{~m}^{3} \mathrm{~s}$ during the wet season (February-May) with maximum flood up to $3300 \mathrm{~m}^{3} \mathrm{~s}$ (Sharifimanesh et al., 2015). The Ghezel-Ozan River is highly meandering up to the Manjil dam and is characterized by multiple riffle-pool sequences and sandy clay alluvial channels. Adjacent to the alluvial channels there are other Quaternary alluvial sediments comprising interbedded clay silt and silty clays. The dominant geochemical unit underlying these sediments is igneous bedrock.

The study site is located beside the Ghezel-Ozan River, approximately 80km northwest of Zanjan city (Figure 1). The study site is about $6.4 \mathrm{~km}$ long. It consists of five meandering areas adjacent to agricultural lands. The geology of the study site is mostly late Tertiary to early Quaternary calcareous sands, clay and basalt which contain groundwater with total dissolved solid (TDS) of 1200-3100 mgl-1 (Toudeshki and Arian, 2011).

\section{Field data sampling}

We chose five sampling locations along the parafluvial zone within the hyporheic zone of the Ghezel-Ozan River in addition to one riverbed sampling point (Figure 1). We installed TLC Solinst Level Loggers (accuracy of \pm 0.05 $\left.{ }^{\wedge} \mathrm{C}\right)$ at two different depths below surface ground $(20 \mathrm{~cm}$ and $100 \mathrm{~cm})$ at points Pz1, Pz2, Pz3, Pz4, and Pz5. We 
used a $1.5 \mathrm{~m}$ long galvanized steel pipe of $70 \mathrm{~mm}$ outside diameter (OD) with an end-fitted steel drive point at each hyporheic sampling points. Data loggers continuously recorded the daily temperature fluctuation the depth of 20 $\mathrm{cm}$ and $100 \mathrm{~cm}$ below the river bed during the seven months of the study period (February-March 2016 and July -September 2016). For stream bed sediment temperature monitoring, we applied an iButton semiconductor temperature logger with accuracy of $\pm 0.5^{\wedge} \mathrm{C}$ installed at a depth of $5 \mathrm{~mm}$ beneath the streambed sediments. The logger was inserted inside the perforated high-density polyethylene (HDPE) pipe with 70mm OD filled with in situ sediments, and a $300 \mathrm{~mm}$ length solid steel rod was attached to firmly fix it in its position.

In addition to the temperature monitoring, the Electrical Conductivity (EC) and ${ }^{222} \mathrm{Rn}$ concentration were measured fortnightly at each hyporheic sampling point ( $\mathrm{H} 1$ to $\mathrm{H} 10)$ as well as in the stream bed water samples that were obtained as close as possible to the hyporheic sampling point. Fourteen data collection trips sampled pore water from $5 \mathrm{~cm}, 20 \mathrm{~cm}, 40 \mathrm{~cm}, 60 \mathrm{~cm}, 80 \mathrm{~cm}$, and $100 \mathrm{~cm}$ depths below the streambed surface and in the stream bed sediment. A multi-level Sampler (MLS) piezometer was used to monitor porewater concerning piezometric head, ${ }^{222} \mathrm{Rn}$ concentration, and temperature at the six aforementioned depths. The MLS is a $16 \mathrm{~mm}$ diameter HDPE central support rod surrounded by several flexible PTFE Teflon sampling tubes. The end part of HDPE tube is fitted with a stainless steel drive point to help the device to penetrate into sediments. Two $4 \mathrm{~mm}$ diameter openings in the bottom of the HDPE tube, $1.7 \mathrm{~cm}$ above the stainless steel pipe joint, monitor the piezometric head before taking the water samples, to guarantee that we measure the natural and not artificially pumped water level. Porewater samples were drawn from the Teflon tubes using a low flow multichannel peristaltic pump. The sample tubes were purged before sampling by discharging three times the volume of water present in the sample tube. The samples for chemical analysis and isotope measurements were filtered through $0.45 \mu \mathrm{m}$ immediately after sampling. All the above-mentioned sampling procedures are depicted in Figure 1.

We measured the concentration of ${ }^{222} \mathrm{Rn}$ and Electrical conductivity in the field at each five hyporheic and stream bed location (Pz1 to Pz5) using RAD7-H2O equipment (Durridge Co., MA, USA) and spectrum EC meter respectively. Moreover, samples from these points were collected in 125-ml plastic reagent bottles sealed with Para-films. All samples were kept at $4^{\wedge} \mathrm{C}$ and transported to an analytical laboratory at the University of ZANJAN to estimate oxygen-18 and deuterium by using Liquid water stable isotope analyzer (Los Gatos Research, CA, USA). Also, at each point of water sampling, two bottles (one liter each) were filled for laboratory analysis. The first bottle was acidified $\left(\mathrm{HNO}_{3}, 2 \% \mathrm{v} / \mathrm{v}\right)$ for Cation analysis and the other bottle was non-acidified for anion assertion. The chemical analyses performed at the chemical laboratory of University of ZANJAN used procedures established as standard methods for the examination of water and wastewater (Cleceri et al., 1998). 


\section{Research Methodology}

To characterize the parafluvial exchange within the hyporheic zone (PEHZ) the following procedures were used:

- Clustering the set of observations via Multivariate and identifying the hydrochemical facies and its associated impact on SW by Surveying the parafluvial and SW ion hydrochemistry,

- Scatter plot of Stable isotope $\left(\sigma D\right.$ vs. $\left.\sigma^{18} \mathrm{O}\right)$ in bore water, Surface water $(\mathrm{SW})$, and parafluvial water as well as the combination of water geochemistry $(\mathrm{EC})$ and heavy isotope $\left(\sigma^{18} \mathrm{O}\right)$; and

- Application of i) temperature recorded time series in the parafluvial water $(20 \mathrm{~cm}$ and $100 \mathrm{~cm})$, ii) diel temperature and radon activity in the representative points at 5,20,40,60,80, and $100 \mathrm{~cm}$ depths to verify the results acquired by integration of $\mathrm{EC}$ and $\sigma^{18} \mathrm{O}$.

\subsection{Multivariate Statistical Analysis}

The best way to qualitatively assess the PEHZ, based on isotopic signature and water hydrochemistry, is the HCA technique (Guggenmos et al., 2011; King et al., 2014). HCA is an unsupervised pattern recognition method which allows the exploratory clustering of observed data sets (Kokot et al., 1998). This grouping of data set is typically based on i) multivariate statistical techniques (Q-mode) and ii) similarity between data. In this study, parameters from groundwater and surface water samples used for $\mathrm{HCA}$ included: major cations $\left(\mathrm{Na}^{+}, \mathrm{K}^{+}, \mathrm{Ca}^{2+}, \mathrm{Mg}^{2+}\right)$, onions $\left(\mathrm{Cl}^{-}, \mathrm{SO}_{4}{ }^{2-}, \mathrm{HCO}_{3}{ }^{-}, \mathrm{NO}_{3}{ }^{-}\right)$and water geochemistry $(\mathrm{EC}, \mathrm{pH})$. The ward linkage method, as well as Euclidean distance measurement techniques, were applied due to their efficacy in water analysis clustering (Güler et al., 2002). This method groups each component, based on the comparison between percentages of similarity between each component which is ideal to identify the inner-connectivity between neighbor points in a limited area (Raiber et al., 2012). The number of clusters was determined based on interpretations drawn from the pictorial illustrated dendrogram. In the final step, the phenon line (Sokal and Rohlf, 1962) was used to split the number of representative and appropriate clusters.

\subsection{Stable isotope of $\sigma^{2} \mathrm{H}$ vs $\sigma^{18} \mathrm{O}$}

Isotopic composition of groundwater is a useful tool to trace stream-aquifer connectivity and the encroachment of surface water in the hyporheic zone (Payne, 1970). The isotopic composition of the groundwater recharge follows the incident precipitation rather swiftly and leads to less than $1 \%$ change in groundwater isotopic composition of the $\sigma^{18} \mathrm{O}$, and $\sigma^{2} \mathrm{H}$ (Gat, 1987). Then, the difference in the composition of $\sigma \mathrm{D}$ and $\sigma^{18} \mathrm{O}$ in parafluvial water, surface water, and groundwater could be used to precisely characterize the mixing process of 
PEHZ. Because evaporation in surface water, for example, causes enrichment of $\sigma \mathrm{D}$ and $\sigma^{18} \mathrm{O}$, the isotopic signature of parafluvial water varies significantly from groundwater, due to groundwater discharge.

The stable isotopes of $\sigma \mathrm{D}$ and $\sigma^{18} \mathrm{O}$ are usually expressed as per mil $(\sigma \%)$ of $2 \mathrm{H} / 1 \mathrm{H}$ and $18 \mathrm{O} / 16 \mathrm{O}$ respectively, with regards to VSMOW (Vienna Standard Mean Ocean Water. $\sigma \%$ is calculated as (Eq. (1)):

$\sigma \%=\left(\mathrm{R}_{\text {sample }} / \mathrm{R}_{\text {standard }}-1\right) * 1000$

Where R represents the ratio of ${ }^{18} \mathrm{O} /{ }^{16} \mathrm{O}$ and ${ }^{2} \mathrm{H} /{ }^{1} \mathrm{H}$

Mixing ratios between SW and parafluvial water are evaluated by an end-member mixing model (Yehdeghoa et al., 1997). The portion of $\mathrm{SW}, \mathrm{P}_{\mathrm{sw}}$, within the parafluvial zone calculated is described in Eq. (2) (Stichler et al., 1986):

where $\mathrm{Y}_{\mathrm{z}}, \mathrm{Y}_{\mathrm{gw}}$, and $\mathrm{Y}_{\mathrm{sw}}$ denote the concentrations of $\sigma{ }^{18} \mathrm{O}$ and $\sigma{ }^{2} \mathrm{H}$ in the mixture, ground-water, and surfacewater end members, respectively. When the portion of SW in the parafluvial zone is $100 \%, \mathrm{P}_{\mathrm{sw}}$ is equal to 1 and vice versa.

\subsection{Spatial and seasonal variability of Parafluvial Flux}

$\mathrm{EC}$ and $\sigma^{18} \mathrm{O}$ are tracers that have opposite functions in groundwater and SW. EC is a measure of the water capability to pass electrical flow which is directly related to the concentration of dissolved ions in the water. The concentration of dissolved salts, like sulfides, chlorides, carbonate, and so on in Groundwater is greater than SW leads to elevation of EC in Groundwater (Rowden, 2008). $\sigma 18 \mathrm{O}$ in surface water is highly affected by evaporation, which causes more enrichment of it in SW than in groundwater (see section 4.2).

In this study, we applied EC and $\sigma^{18} \mathrm{O}$ to develop a parafluvial flux assessment tool in combination with defining a generalized separator line to distinguish the gaining and losing reaches within the parafluvial zone of the study site. These procedures were conducted at multi-level scale $(20 \mathrm{~cm}$ and $100 \mathrm{~cm}$ depth below the stream bed sediments) and during the wet and dry season. The divider line was defined based on the opposing isotopic and geochemical characteristics of EC and $\sigma^{18} \mathrm{O}$ at SW and Groundwater. In this regard, the area of the framework with the depleted electrical conductivity and enriched $\sigma^{18} \mathrm{O}$ proposed the water originated from SW due to groundwater recharge (losing stream). The opposite hypothesis applies for the groundwater discharge (gaining stream). The parts of the framework with similar characteristics to either $\mathrm{SW}$ or groundwater for $\mathrm{EC}$ or $\sigma^{18} \mathrm{O}$ are 
supposed to be neutral. The coordinate of points, based on the characteristics above, are defined in Eq. (3) and Eq. (4) as the coordinates of the final border and divider line, respectively:

Final border coordinate $=\left[\sum\left(\mathrm{EC}_{\mathrm{b}} / \mathrm{n}\right), \sum\left(\delta 18 \mathrm{O}_{\mathrm{b}} / \mathrm{n}\right)\right]$

Divider point $=\left[\left(\mathrm{EC}_{\mathrm{b}}(\right.\right.$ average $)+\mathrm{EC}_{\mathrm{sw}}($ average $\left.)\right) / 2,\left(\delta 18 \mathrm{O}_{\mathrm{b}}(\right.$ average $)+\delta 18 \mathrm{O}_{\mathrm{sw}}($ average $\left.\left.)\right) / 2\right]$

where

$\mathrm{EC}_{\mathrm{b}}, \mathrm{EC}_{\mathrm{sw}}, \delta^{18} \mathrm{O}_{\mathrm{b}}$, and $\delta^{18} \mathrm{O}_{\mathrm{sw}}$ refer to bore water electrical conductivity, surface water electrical conductivity, and heavy isotope of oxygen in bore water and SW, respectively. By drawing two perpendicular lines parallel to the $\mathrm{EC}$ and $\delta 18 \mathrm{O}$ axis, the framework is divided into four parts with previously mentioned characteristics. The results obtained by this procedure were verified by the application of the pre-established methods, temperature and ${ }^{222} \mathrm{Rn}$.

\subsection{Radon}

Radon $\left({ }^{222} \mathrm{Rn}\right)$ is a radioactive noble gas with a half-life of 3.8 days. Radon is produced by the radioactive decay of uranium-series isotopes (Burnett et al., 2010b). The decay of uranium isotopes attached to the aquifer matrix, within the saturated zone, produces radon which is immediately dissolved in the subsurface matrix and after groundwater containing radon outflows to surface water bodies, radon concentrations decrease due to gas exchange with the atmosphere (which is low in radon) and radioactive decay. Therefore, high radon concentrations are present in surface waters only in the immediate vicinity of points of groundwater outflow and for relatively short distances downstream of such locations (Lee and Hollyday, 1993).

\subsection{Temperature}

Measurement of diel vertical temperature variation and multi-level daily temperature time series have been used in this study to verify the results acquired by integration of EC and $\sigma 18 \mathrm{O}$ (section 4.3). Temperature time series were applied to assess the gaining /losing reaches using the method described by Silliman and Booth (1993). The vertical temperature time series was measured at $20 \mathrm{~cm}$ and $100 \mathrm{~cm}$ depths below the river bed at the representative sampling points and atS1, S2. Furthermore, the change in the daily temperature at 5, 20, 40,60, 80 , and $100 \mathrm{~cm}$ depth was measured in the afternoon $(2.30 \mathrm{pm})$ and dawn $(5.30 \mathrm{am})$ to obtain vertical flux upward/ downward movement in the representative parafluvial sampling points.

The use of sediment bed temperature anomaly was first introduced by Silliman and Booth (1993) to assess gaining/ losing points qualitatively. They conducted a set of experiments to record the temperature anomalies at different depths which provide an excellent indicator of groundwater flow patterns. Constantz (1998) concluded 
that the diel fluctuation of temperature in sediment bed is greater for losing stream than gaining stream compared with shallow groundwater temperature variation. This difference is due to the influence of daily changes in SW temperature and their impact on water viscosity, density, and subsequently the hydraulic conductivity of shallow groundwater (Constantz et al., 1994; Ronan et al., 1998).

On the other hand, temperature envelopes (vertical fluctuation of diel temperature) in shallow groundwater provide evidence of flux downward/ upward movement through the near surface sediment system (Baskaran et al., 2009). Furthermore, distinct multi-level seasonal path shifts can be further observed by scrutinizing the vertical variation of diel temperature.

\section{Results and Discussion}

\subsection{Multivariate Statistical Analysis}

At the first step, all variables, including major cations, onions and water geochemistry (EC) undergo logarithm transformation. Then, by applying the nearest neighbor linkage rule (statgraphics Centurion XVI, version 16.02.04), outliers were identified. For the dry season B6 and B2 and for the Wet season B3 and B5 were identified as the outliers, since there was no obvious correlation between these sampling points within the study site. It is likely that the analytical results obtained from these outliers are biased by data reporting errors and the possible errors occurred during the sampling procedure. So these points were excluded from this study. The remaining groundwater and surface water sampling points were subjected to HCA. Figure $2 \mathrm{a} \& \mathrm{~b}$ show the dendrograms obtained from the HCA for the dry season and wet season, respectively. As mentioned by Daughney and Reeves (2006), variation in the separation threshold lets us recognize the lower or higher number of clusters visually. For this study, two different clusters for each seasonal pattern (wet and dry) seem to be appropriate. Two distinct patterns of clustering in PEHZ which varied from dry season and wet season, assist us to better scrutinize the PEHZ more accurately especially during the transition of the seasons. This scheme has been confirmed by Güler and Thyne (2004). Also, inclusion of one surface water sampling point in each cluster makes the accurate interpretation of GW-SW interaction possible. In dry season, cluster1 (C1) includes S1 with H1, H2, H3, H10, B1, B2 sampling points and cluster 2 (C2) includes S2 with $\mathrm{H} 4, \mathrm{H} 5, \mathrm{H} 6, \mathrm{H} 7, \mathrm{H} 8$, H9, B4, B5 sampling points as well as in wet season s1, H1, H2, H3, H4, H5, H10, B1, B2, B6 points considered as Cluster 1 (C'1) and S2, H6, H7, H8, H9, B4 points included in Cluster 2 (C'2) (Figure 2).

\subsection{Hydrochemistry of SW and Parafluvial Water}


The seasonal and spatial distribution of the GW hydrochemical properties in the wet season and dry season (Figure 3) is illustrated by using a trilinear piper diagram (Piper, 1944). There is considerable variation in the relative major ion chemistry in the study area during the wet and dry season. These hydrochemical differences indicate diverse hydrochemical facies which demonstrate the possibility of distinct parafluvial flow mechanisms. Comparison of S1 and S2 with $\mathrm{H} 1$ through $\mathrm{H} 10$ highlights that these two water bodies have almost the same characteristics during the wet season, with the $\mathrm{CaHCO} 3$ water type and the high proportion of $\mathrm{Ca}$ in the two water bodies suggesting the occurrence of ground water recharge (Dixon-Jain, 2012). The mean values of the major ion chemical properties of the study area for C1, C2, C'1, and C'2 are described in Table 1 The low value of EC, especially in the wet season, corroborates the fact that water in the parafluvial zone is generally diluted, possibly type aquifer matrix and two water bodies (Werner et al., 2007).

In the dry season, ground water is mainly $\mathrm{NaHCO} 3$ type, for which $\mathrm{HCO} 3$ and $\mathrm{Na}$ are the dominant anion and cation respectively, with a low value of $\mathrm{Ca}$ (Table 1). The close vicinity of S1, H3, H2 and S2, H7, H8, shows that They exhibit similar hydrochemical proportions. From this, a high degree of parafluvial water-river water interaction can be inferred. The same analysis has been reported by Forsmark (2007). In the wet season, HCO3 and $\mathrm{Ca}$ are the most dominant anion and cation respectively (Table 1). Furthermore, The pivotal change in the features of PEHZ cab be inferred by considering the shift of dominant cation type in the wet season (Na) and dry season $(\mathrm{Ca})$ and the presence of $\mathrm{HCO} 3$ as the dominant anion type, as well as comparing with the S1 and S2 (Figure 3).

While, the piper diagram provides beneficial information dealing with water chemistry and the stream-aquifer connectivity, alone it lacks the ability to represent accurately the seasonal and spatial alterations in HW-RW. For this reason, a combination of several environmental tracer methods has been suggested (Fleckenstein et al., 2010) to better conceptualize and evaluate the mixing patterns of GW-SW interaction.

\subsection{The stable isotope ratio}

The mixture of rainfall with pre-existing water in a system and evaporation (Kendall and McDonnell, 2012) causes variation in the isotopic composition of rainfall, making the deviation in the stable isotope signature inevitable. The conservative and non-reactive naturally occurring water isotopes, $\sigma 18 \mathrm{O}$ and $\sigma \mathrm{D}$, have been recognized as effective tools to recognize the mixing process between several source waters (Woocay and Walton, 2008). The relationship between $\sigma \mathrm{D}(\%, \mathrm{SMOW})$ and $\sigma 18 \mathrm{O}(\%, \mathrm{SMOW})$ is scrutinized ,In this study, at multiple levels for 
dry season with respect to Global Meteoric Water Line (GMWL)(Craig, 1961) and Local Meteoric Water Line (LMWL) (Shalmani et al., 2016) respectively.

The isotopic signature of parafluvial water (H1-H10), surface water (S1, S2) and bore waters (B1 to B6) follow the same clustering procedure (section 5.1), but in each cluster and for different seasonal conditions the water's isotopic composition in the parafluvial zone is measured at two depths $(20 \mathrm{~cm}$ and $100 \mathrm{~cm})$ to better delineate the PEHZ. In this regard, for dry season C1-20, C1-100, C'2-20, and C'2-100 refer to measuring the water stable isotope signature (just hyporheic water measured in two depths the other points have no changes) at $20 \mathrm{~cm}$ and $100 \mathrm{~cm}$ for $\mathrm{C} 1$ and $\mathrm{C} 2$.

\subsubsection{Low flow condition}

10 The isotopic composition of bore water, $\mathrm{SW}$, and parafluvial water at $20 \mathrm{~cm}$ and $100 \mathrm{~cm}$ below the surface is illustrated in Figure 4. The isotopic composition of parafluvial water varies between bore water and SW, there is high degree of evaporation in SW samples due to more enriched values of isotopic signature which range from $9.96 \%$ to- $19.8 \%$ and from $-1.88 \%$ to- $3.59 \%$ for $\sigma 18 \mathrm{O}$ and $\sigma \mathrm{D}$ respectively. The enriched value of heavy isotopes in SW and parafluvial waters follow an evaporative line, sloping away to the right side of LMVL.

The isotopic signature of C1-20, C1-100, C2-20, and C2-100 is described in Table 2. The low d-excess values mirror the effect of evaporation in sampling locations and give the results obtained from the comparison of the enriched heavy isotopes in the parafluvial zone and bore waters (Figure 4). The isotopic composition of S1 and S2 is highly enriched with d-excess values of 2.15 and 3.3 (Table 2). This feature demonstrates the strong influence of evaporation on surface water, where transmission of the thermal heterogeneity and enriched heavy isotopes in SW to the nearby Parafluvial sampling points affect the isotopic composition of groundwater and cause depletion of the d-excess values in the parafluvial zone. Furthermore, the isotopic composition of bore samples at B1 is close to $\mathrm{H} 1$ and $\mathrm{H} 10$, and $\mathrm{B} 3$ is close to $\mathrm{H} 3, \mathrm{H} 4$, and $\mathrm{H} 5$ and well distributed along the LMWL, which suggests the groundwater is the source of surface water in the dry season and the dominance of discharge in PEHZ is evident.

Isotope mass balance measurements using the two-component mixing model (described in the methodology section) demonstrate that the highest fraction of ground water discharge ( $\left.\mathrm{P}^{\prime} \mathrm{gw}\right)$ occurred in August and the lowest in September. Reduction in the contribution of groundwater in surface water in September may be caused by rainfall $(25 \mathrm{~mm})$ at mid-September (13.06.2016) which reduced the dependency of surface water on groundwater. In August the 84 and 87percent of parafluvial water discharged into SW at $\mathrm{C} 1$ and $\mathrm{C} 2$ respectively (Table 2). 
The isotopic signature of hyporheic water in $\mathrm{C} 1$ especially at $\mathrm{H} 1$ and $\mathrm{H} 3, \mathrm{C} 2$ especially at $\mathrm{H} 5$, and $\mathrm{H} 7$ is slightly enriched and lies between the value of $\mathrm{B} 5$ and $\mathrm{S} 1$ for $\mathrm{C} 1$ plus, $\mathrm{B} 4$ and $\mathrm{S} 2$ forC2, all of which follow the same patterns at different depths. This feature in the isotopic signatures provides the evidence of possible hydrogeological interaction with the surrounding subsurface system.

Variation in the $\sigma 18 \mathrm{O}$ and EC are highly concurrent with each other at $20 \mathrm{~cm}$ and $100 \mathrm{~cm}$, and as with the river discharge fluctuation, there is a positive correlation between EC and $\sigma 18 \mathrm{O}$ and river discharge (Figure 5a\&b). The values of $\sigma 18 \mathrm{O}$ and $\sigma \mathrm{D}$ correlate strongly, especially at $20 \mathrm{~cm}$ depth, and in H6-July, H5-July, H5-August, H6-August, H7- August, H8-August and H10-September, which reveals the connectivity of parafluvial water and $\mathrm{SW}$ in shallow depths. Accordingly, we used the results of $\sigma 18 \mathrm{O}$ and all conclusions are valid for $\sigma \mathrm{D}$. In C1-20 the value of $\sigma 18 \mathrm{O}$ at $\mathrm{S} 1$ is more highly enriched than $\mathrm{H} 1, \mathrm{H} 2, \mathrm{H} 3$, and $\mathrm{H} 10$, with the lower values of EC due to groundwater outflow, especially in August when parafluvial water has the greatest contribution to SW. Comparison between $\sigma 18 \mathrm{O}$ and $\mathrm{EC}$ at two depths, using the $\mathrm{SW}$ values as a basis for this estimation, indicates the dominance of groundwater outflow (discharge). For instance, at H1 in July the value of $\sigma 18 \mathrm{O}$ depleted from $2.73 \%$ to $-2.89 \%$ and $\mathrm{EC}$ increased from 425.55 to 458.27 at $20 \mathrm{~cm}$ and $100 \mathrm{~cm}$ respectively ( $\mathrm{S} 1$ which is -1.76 and 430.74). This indicates the higher degree of inner-connectivity between SW and $\mathrm{H} 1$ at $20 \mathrm{~cm}$ depth and the upward movement of water from $100 \mathrm{~cm}$ to $20 \mathrm{~cm}$ (The similar analyses are valid for all other points and while the monthly outcome of it is represented in Figure 5).

Figure 5 shows that the values of the isotopic composition at $20 \mathrm{~cm}$ are more enriched than at $100 \mathrm{~cm}$ and are close to the subsequent values of surface water, except $\mathrm{C} 2$ at $\mathrm{H} 4$, and H5. This discrepancy in depth is possibly due to hyporheic recharge at the depth of $20 \mathrm{~cm}$ during dry seasons. This similarity is because of the different soil texture in pz3, sandy loam with sand content greater than $45 \%$, which facilitates the transportation of highly enriched surface water in shallow groundwater. By further scrutinizing the result of parafluvial samples, the lower value of EC in the surface water in comparison with parafluvial sampling points demonstrates greater similarity of higher hyporheic components than is typical. All of the aforementioned characteristics demonstrate that the inner connectivity of between alluvial aquifer and river bank at $\mathrm{H} 1, \mathrm{H} 3, \mathrm{H} 5, \mathrm{H} 7$, and $\mathrm{H} 9$ are probably due to hyporheic discharge. Similar analyses apply for all other points and the monthly outcome of EC and $\sigma 18 \mathrm{O}$ for all points and at the two depths is represented in Figure 5.

In order to better delineate the stream-aquifer connectivity, the authors used two elements in surface water and groundwater that behave in an opposite manner, EC and $\sigma 18 \mathrm{O}$. EC in groundwater is higher than SW (Yan et al., 
2013) while the opposite is true for $\sigma 18 \mathrm{O}$ (Yeh et al., 2014). Simultaneous application of these components in a unified framework is an innovative means to recognize the gaining and losing reaches (Santucci et al., 2017). Where the inflow of enriched SW (Figure 4) into the parafluvial zone enriches the heavy isotope composition in the parafluvial zone compared with intact bore waters and outflow of bore waters into stream with the highest value of EC (Figure 5). This status causes an immediate enhancement in the values of EC in parafluvial water compared with river bed water sediments (Santucci et al., 2017). In the majority of points EC and $\sigma 18 \mathrm{O}$ have contradictory fluctuation, except H6-July, H5-July, H5-August, H6-August, H7- August, H8-August and H10September at $20 \mathrm{~cm}$ depth and in H6-August, and H10-September at $100 \mathrm{~cm}$. Also, $\sigma 18 \mathrm{O}$ at $\mathrm{S} 1$ and S2 is more enriched than parafluvial points (H1 to H10), which slightly depleted in September due to an increase in river discharge and a lesser effect of evaporation on SW. River discharge diminishes from July to August and has a slightly incremental trend in September from $0.35 \mathrm{~m}^{3} / \mathrm{S}$ in August to about $2.4 \mathrm{~m}^{3} / \mathrm{S}$ in September with enriched $\sigma 18 \mathrm{O}$ and low value of EC in S1 and S2 as well as depleted value of $\sigma 18 \mathrm{O}$ and increase in EC. This could be on account of low effect of SW on Parafluvial water and possibility of groundwater outward movement.

To better pinpoint the monthly variation of PEHZ in parafluvial sampling points, this study proposes the integration of EC and $\sigma 18 \mathrm{O}$, to accurately estimate the gaining, losing, or neutral parafluvial flow patterns. The monthly results of this analysis, in dry season, are illustrated in Figure 6. in gaining stream parafluvial water characteristics should be closer to bore water, with high EC and depleted $\delta 18 \mathrm{O}$, while in losing stream the characteristics of the parafluvial water should be close to SW, with low EC and enriched $\delta 180$. Theses linemates lead to delineation of specific separation lines for gaining/losing streams ,in point scale. Based on that, the perpendicular lines crossed from $\left[\left(\mathrm{EC}_{\mathrm{b}}(\right.\right.$ average $)+\mathrm{EC}_{\mathrm{sw}}($ average $\left.)\right) / 2,\left(\delta 18 \mathrm{O}_{\mathrm{b}}(\right.$ average $)+\delta 18 \mathrm{O}_{\mathrm{sw}}($ average $\left.\left.)\right) / 2\right]$ point and parallel to EC and $\delta 180$ axises are defined as the separating line between losing, neutral, and gaining reaches (section 4.3).

The majority of parafluvial points, especially in August, appear in the gaining stream part which confirms the results of two-component mixing model ( $\mathrm{F}_{\mathrm{gw}} \approx 85 \%$ ) and the outward movement of groundwater in the majority of parafluvial points in July. The results of Figure 6 are in good agreement with the results depicted in Figure 5, in which the dominance of groundwater inward movement at $100 \mathrm{~cm}$ (especially in September) and groundwater outward movement at $20 \mathrm{~cm}$ (especially in July and August) prevailed. Furthermore, by further surveying the radon activity and Temperature, the vertical flow directions are defined. The vertical flow direction has been estimated by simultaneous application of radon activity and temperature variation at 5,20,40,60, 80, and $100 \mathrm{~cm}$ depths, as described in section5.5. 


\subsubsection{High Flow Condition}

Figure 7 illustrates the isotopic composition of bore water (B1to B6), SW (S1, S2) and parafluvial water (H1 to

H6) during the wet season (FEB-MAY) which tracks well with the LMVL. The isotopic composition of C'1-20,

C'1-100, C'2-20and C'2-100 is illustrated in Table 3. The isotopic composition of sampling points varies from -

4.04 to -4.18 and from -24.06 to -31.08 for $\sigma 18 \mathrm{O}$ and $\sigma \mathrm{D}$, respectively. The high values of d-excess for surface water stations refer to the low effect of evaporation on the isotopic composition of surface water. Figure $8 \mathrm{a} \& \mathrm{~b}$ shows the values of EC and $\sigma 18 \mathrm{O}$ for each month. In the April and May an increase in the river discharge makes the value of EC decrease and the heavy isotope deplete. This characteristic refers to the effect of groundwater recharge on the isotopic signature and geochemistry of parafluvial water. As depicted in Figure 8a, the isotopic signature of parafluvial water at $20 \mathrm{~cm}$ depth is close to surface water because of the high infiltration rate of surface water to hyporheic water at $20 \mathrm{~cm}$ below surface ground. Accordingly, there is greater variation between hyporheic water and surface water in $100 \mathrm{~cm}$ depth (Figure 8b). Also, the isotopic composition of the groundwater at $\mathrm{H} 2, \mathrm{H} 4, \mathrm{H} 6, \mathrm{H} 8$, and $\mathrm{H} 10$ is more depleted in the heavy isotopes than the adjacent surface water, which indicates the existence of lateral groundwater recharge. The two-component mixing model demonstrates the low percentage of groundwater discharge (P'gw) in the wet season, especially April and May, which indicates that only 3 to 5 percent of water in the parafluvial zone discharges into the river and more than 95 percent of PEHZ is due to groundwater recharge (Table 3).

River discharge during wet season varies from $4.2 \mathrm{~m} 3 / \mathrm{S}$ in February to about $32 \mathrm{~m} 3 / \mathrm{S}$ in April. It appears that an increase in the river discharge (especially in April and May) causes the EC in parafluvial zone to decrease. In the majority of points (except H10-March H3-April, H4-April, H10-May at $20 \mathrm{~cm}$ depth and H9-March, and H7 May at $100 \mathrm{~cm}$ depth) the values of EC and $\sigma 180$ present opposite correlations as well as heavy decrease and slight enrichment in the values of EC and $\sigma 18 \mathrm{O}$ in S1 and S2 respectively. The drop in the EC and $\sigma 18 \mathrm{O}$ at SW, especially in April and March, and the presence of heavy river discharge demonstrate the lower effect of evaporation on the isotopic signature of surface water in which transmission of the SW isotopic and geochemical characteristics to parafluvial water result in a decrease in the parafluvial water geochemical composition as well as a slight increase in the isotopic composition of parafluvial water.

These different characteristics of two adjacent water bodies suggest the relatively strong connection between two adjacent water bodies with respect to the dominance of aquifer recharge. To better quantify this process (PEHZ in wet season), the same procedure to evaluate two different end members with opposite features (EC and $\delta 18 \mathrm{O})$ 
in parafluvial water and surface water was carried out to pinpoint the gaining (discharge), neutral, and losing (recharge) characteristics of each parafluvial sampling point (Figure 9). The majority of points in the study site behave as losing stream or neutral, with no sign of groundwater discharge. The results shown in Figure 9 confirm that in the wet season most of the river water outflows into the parafluvial zone. The effective depth and type of PEHZ can also be recognized by this method. Most of the groundwater inflow happens at a depth of $20 \mathrm{~cm}$ below surface and points at $100 \mathrm{~cm}$ have a mostly neutral status. Some points like H1-Feb, H1-Mar, H5-Mar, H10-Mar, H1-Apr, H2-Apr, H10-Apr, H1-May, H2-May, H3-May, H5-May, H10-May show similar losing characteristics at both depths.

Finally, the comparison of surface water, bore water, and parafluvial water stable isotope signature and geochemical composition at different depths with regard to high flow and low flow condition confirms the high seasonal and spatial fluctuation in the PEHZ flow while the direction of PEHZ varies a great deal from point to point and in different flow conditions. These results are in accordance with previous studies performed in other countries (Fox et al., 2016; Wu et al., 2017). Furthermore, the isotopic composition of hyporheic water varies with depth in different seasons, as in the dry season the most groundwater discharge happens at greater depth of subsurface water $(100 \mathrm{~cm})$, while in wet seasons the shallow water parafluvial interaction $(20 \mathrm{~cm})$ is detectable. These characteristics are rarely studied and require further investigation in multiple countries and different weather conditions to establish the credibility of the methods introduced in this study. Also, as shown in Table 2 and Table 3, the fractionation of parafluvial water outflow to surface water is higher in dry seasons than in wet seasons, which poses a potential risk of surface water quality deterioration due to hyporheic water infiltration, especially in dry season, and in conditions where the possibility of parafluvial discharge predominates.

\subsection{Time Series of the Temperature Oscillation}

Advective transport of heat reveals distinct thermal patterns to losing versus gaining stream (Constantz et al., 2003). A qualitative investigation of gaining versus losing streams was first introduced by Silliman and Booth (1993) who used sediment bed and shallow groundwater daily temperature time series. Based on this method, we investigated the qualitative relationship between sediment bed temperature and a parafluvial water temperature time series to validate the accuracy of the results obtained in Section 5.3. In order to avoid repetitive analysis, points show similar gaining or losing status at both $20 \mathrm{~cm}$ and $100 \mathrm{~cm}$ depths were chosen as a criterion and representative of whole study site. So in dry season and for gaining conditions, points H1, H2, H3 in July and in August H1 and in September H1, H8, for losing stream condition in September H3 (no reported losing stream 
the aforementioned points during dry season. In the all gaining locations, the parafluvial temperatures vary slightly, registering only small temperature fluctuation during the day, even reducing from $20 \mathrm{~cm}$ to 100 depth. The difference between maximum and minimum recorded daily temperature for $\mathrm{H} 1$, for example, at July in the river sediment, $20 \mathrm{~cm}$ and $100 \mathrm{~cm}$ were $3.51^{\wedge} \mathrm{C}, 0.86^{\wedge} \mathrm{C}$ respectively (Table 3 ). As is evident from Table 3 and

Figure 10, temperature in the river sediment fluctuated extensively throughout the day on account of hot and dry weather conditions during the dry season (daytime temperature was above $29^{\wedge} \mathrm{C}$ ) and hence, the relatively cool SW and cooler parafluvial water with constant temperature was completely aligned with the results obtained in Section 5.3, which provides strong evidence of groundwater outflow. Seasonal temperature oscillations and lag time between amplitude of parafluvial water and streambed sediment temperatures, and temperature damping at reverse resonance with sediment bed temperature, with slight diurnal variation $\left(0.6-2^{\wedge} \mathrm{C}\right)$. The slighter diurnal temperature variation in parafluvial water than sediment bed $\left(5\right.$ to $\left.6^{\wedge} \mathrm{C}\right)$ is probably due the fact that the downward propagation of surface water temperature is moderated by the groundwater's upward movement from depth, where temperature is relatively constant on the daily time scale.

Seasonal temperature oscillations and lag time between the amplitude of parafluvial water and streambed sediment temperatures, and temperature damping at $20 \mathrm{~cm}$ depth with lesser amplitude at $100 \mathrm{~cm}$ depth are evident. The parafluvial temperature shows a reverse resonance with sediment bed temperature and a slight diurnal signal was detected in the parafluvial water, which typically indicates the dominance of gaining conditions.

Figure 11 depicts how changes associated with sediment bed Temperature affected the parafluvial water temperature during the wet season. The response at $20 \mathrm{~cm}$ possesses higher intensity than $100 \mathrm{~cm}$ depth.This can be construed as the extensive inflow of groundwater at these points. Furthermore, the close conformity of sediment bed and parafluvial water temperature oscillations with slight shifts in variation and decreased amplitude affirms the evidence that these temperature oscillations are a response to groundwater recharge. As a consequence of the same schema of sediment bed vacillation the maximum and minimum values of temperature in August and September, described in Table 4, are not constant over the time.

The phase and amplitude of the stream bed sediment temperature oscillation are very similar to the corresponding parafluvial water temperature variation at $20 \mathrm{~cm}$ and $100 \mathrm{~cm}$, which reveals the facilitated stream outward flux and heat transport, due to high permeability of streambed sediments. The regular parafluvial water temperature oscillations are related to the stream bed signal, since transport of warmer SW into the parafluvial zone of lower 
temperature causes a slight increase in the parafluvial water temperature. The parafluvial water temperature at $20 \mathrm{~cm}$ and $100 \mathrm{~cm}$ shows an excellent resonance with sediment bed temperature, with similar lag time and decreased trend at $20 \mathrm{~cm}$ and $100 \mathrm{~cm}$ depths. This is due to the downward flow of SW and the advective transport of heat, resulting in deeper diffusion of diurnal temperature oscillation into the sediment bed profile. Parafluvial water temperature oscillation coincides with the sediment bed temperature oscillation, reflecting the stream leakage.

Sediment temperature measured at $20 \mathrm{~cm}$ represents a diurnal signal variation of about $5^{\wedge} \mathrm{C}$, with a 3 -hour peak lagging from the subsequent maxima in the stream bed daily temperature. At the deeper depth the diurnal pattern is more subtle in amplitude, with a 5-hour time lag. This reflects the total time required to transfer heat by both advective and conductive downward movement through sediments.

\subsection{Temperature and Radon Vertical Profiles for Assessment of Parafluvial Vertical Movement and PEHZ}

Point measurement of temperature and radon activity at the representative sampling points was conducted to further characterize PEHZ (Figure 12). Temperature and radon were measured in the field at the same time $\left(13^{\text {th }}\right.$ of July, August, September, and $16^{\text {th }}$ of February, March, April, and $15^{\text {th }}$ of May 2016). Temperature values were measured at two times: at dawn $(6.00 \mathrm{am})$ and in the afternoon $(14.00 \mathrm{pm})$. The values at different depths are depicted in Figure 12. The vertical hydraulic gradient between the riverbed and $100 \mathrm{~cm}$ depth varies from 0.024 to -0.031 (the values on the bottom of each profile in Figure 12). The greatest values of the vertical hydraulic gradient were observed at H10-Feb, H5-May, H5-March, H3-Sep, H1 May, and H1-Aug as well as the highest diel temperature oscillations.

The other points, including H1-Jul, H2-Jul, H8- Sep, H1-Mar, H1-Apr, and H3-Jul generally show a sharp increase in radon activity and attenuated diel temperature variations. The radon activity at lower depth, especially at H1Mar and H10-Feb, which changes from $1.8 \mathrm{~Bq} / \mathrm{L}$ to $4 \mathrm{~Bq} / \mathrm{L}$ and2.9 $\mathrm{Bq} / \mathrm{L}$ to $5.3 \mathrm{~Bq} / \mathrm{L}$ at $20 \mathrm{~cm}$ and $60 \mathrm{~cm}$ depths respectively, is possibly due to the heterogeneous production rates of radon in the river sedimentbed. As hypothesized by Lamontagne and Cook (2007) sedimentbed mineral heterogeneity or radium adsorption (both radon and radium are decay product of uranium (Vinson et al., 2009)) into metal oxides (at the redox boundary) causes an increase in radon activity. Therefore, the abrupt increase in radon activity at H1-Mar and H10-Feb is due to hyporheic biogeochemical procedure or heterogeneity associated with sedimentbed mineralogy.

Due to significant diel temperature oscillation and relatively low constant radon activity, especially at the shallow depths, H10-Feb, H1-May, H5-May, H5-Mar, H3-Sep, and H1-Aug appear to exhibit downward flux. However, 
at the greater depths, between $60 \mathrm{~cm}$ to $100 \mathrm{~cm}$, there might be an upward water flux due to lower temperature variation and elevated radon activity, particularly for H3-Sep, H1 Mar, and 40 to 100cm for H3-Jul, and H1-Aug respectively. These variations in the temperature and radon activities at one point indicate an opposing water flow direction at these depths. The appearance of these contradictory flow paths suggests that PEHZ is affected by the larger scale groundwater regional flow-field, with downwelling movement at the shallow groundwater and upwelling flow at deeper groundwater. Moreover, this finding affirms that the results depicted in Figure 6 and 9 , which demonstrated the opposing gaining/losing characteristics at different depth of the same points, can be inferred from the fact that the parafluvial zone of the study site is firmly enclosed, with bounded regional flowfield. The same analysis has been reported by Cranswick et al. (2014).

The sharp elevation in the values of radon activity from $20 \mathrm{~cm}$ to $100 \mathrm{~cm}$ depths, in association with attenuated diel temperature variation at depth in H8-Sep, H1-Apr, H1-Mar, H9,May, H1-Ju, H2-Jul, can be interpreted as significant influence of SW on the geochemical characteristics of the parafluvial water that might be due to hyporheic upwelling flux. Moreover, the sharp transition from low radon activity in the river sedimentbed to higher radon activity with considerable attenuated diel temperature oscillation is due to circulation of the shallow parafluvial flowpaths which embed within regional groundwater flowpaths (similar analysis was reported by Fox et al. (2016)).

The results obtained from vertical assessment of diel temperature oscillation and radon activity (Except H3-Sep and H1-Mar) are completely in accordance with the results of EC and $\sigma 18 \mathrm{O}$, which demonstrates the probability of complex parafluvial mixing patterns within the hyporheic exchange zone in the study site.

\section{Conclusions}

Integrated analysis of stable isotope and EC provides a promising means to estimate the spatiotemporal variations of stream-aquifer connectivity at different vertical levels examined in this study. Analysis of $\delta^{18} \mathrm{O}$ and $\delta \mathrm{D}$ at various depths $(20 \mathrm{~cm}$ and $100 \mathrm{~cm}$ below the streambed sediments) and within the hyporheic zone. The integration of water stable isotopes with EC as a single framework was infrequently applied and verified in other studies.

This procedure was followed by hydrochemical analysis of bore water, surface water, and parafluvial water, which was supported by continuous and seasonal measurement of temperature and point scale measurement of ${ }^{222} \mathrm{Rn}$ and temperature in order to verify the validity of results obtained by analysis of $\delta^{18} \mathrm{O}$ and EC. This integration created a unique qualitative tool to pinpoint the discharge and recharge areas within the hyporheic zone along the meandering streams (PEHZ) as well as their associated seasonal variations. The key findings of this study are: 
- Analysis of major ion geochemistry in the parafluvial zone revealed considerable seasonal variations. In the dry season $\mathrm{HCO} 3$ and $\mathrm{Na}$ are the major anion and cation type, while $\mathrm{HCO} 3$ and $\mathrm{Ca}$ are the major ion types during the wet season. However, through comparison of the major ion geochemistry in the parafluvial zone and subsequent SW sampling points, a high degree of parafluvial water-surface water exchange could be inferred, but multi-methods analysis is required for qualitative spatiotemporal characterization of PEHZ.

- The isotopic composition of parafluvial water $(\delta 18 \mathrm{O}, \delta \mathrm{D})$ in the dry season is depleted in comparison with SW and enriched in comparison with bore water. Furthermore, the comparison of the isotopic signature of SW, Parafluvial water, and bore water clarified the strong influence of surface water in parafluvial shallow water. The enriched value of $\delta 18 \mathrm{O}$, as well as increase in EC, connotes the effect of groundwater outflow on the isotopic composition and geochemistry of SW in both.

- The isotopic composition of parafluvial water is more enriched than SW and bore water during the wet season. Comparison of the SW and parafluvial water geochemistry and EC, represented similar trends, indicating the dominance of groundwater inflow.

- Multi-level integration of $\delta 18 \mathrm{O}$ and EC yields a monitoring framework to pinpoint the gaining/losing reaches and authenticates the seasonal and spatial variation of PEHZ. In the dry season groundwater outflow prevails in the majority of sampling points and mostly occurs at $100 \mathrm{~cm}$ depth. Whereas during the wet season in the majority of points, groundwater inflow occurs mainly at $20 \mathrm{~cm}$ depth with no sign of outflow.

- Even though, Diel variation in parafluvial sediment temperature $(20 \mathrm{~cm})$ during the dry season is lower than in the wet season, diurnal temperature oscillation of the stream in the dry season $\left(5\right.$ to $\left.6^{\wedge} \mathrm{C}\right)$ is higher than in the wet season $\left(2\right.$ to $\left.3^{\wedge} \mathrm{C}\right)$. This is most likely on account of the absence of any moderating effect from groundwater outward flux in the wet season. This typically indicates that during low flow season, groundwater outflow and in high flow season ground water inflow in dominant.

- The point scale measurement of diel temperature and radon activities at 5,20,40,60,80, and $100 \mathrm{~cm}$ depths (along the parafluvial zone of the river) confirm the results yielded by multilevel integration of $\delta 18 \mathrm{O}$ and EC. Also, by scrutinizing the radon activity and diel temperature oscillation, it was deduced that PEHZ was highly affected by the circulation of a larger scale regional flow-field which the parafluvial zone is enclosed within. 
Using multiple methods, including EC, water Isotopes $(\delta 18 \mathrm{O}, \delta \mathrm{D})$, temperature and radon, yields an innovative alternative monitoring framework and screening tool to qualitatively assess shallow groundwater-surface water interaction on different seasonal and spatial scales. It should be noted that this approach has several potential restrictions, such as limitations posed by geological setting (diffuse groundwater inflow), stratigraphy of the stream bed, or limitations associated with weak thermal and isotopic signatures of parafluvial water. Despite these limitations, the procedure provided highly acceptable outcomes to qualify parafluvial outflow/inflow along the Ghezel Ozan River. The integration of isotopic tracer and geochemical tracers with opposite signatures in surface water and groundwater can lead to achieving qualitative assessments of hyporheic exchange. Thus, further application of this approach to verify the validity of the procedure introduced in this study is a precursor to more detailed studies of hyporheic water-river water interaction, in various regions and climatic conditions, is strongly recommended. The methods introduced in this study should be used to assess the change in transmission rate of water in the parafluvial zone, due to fluctuation of stream water temperature and associated diurnal seepage flux oscillation (because of temperature influence on water density and dynamic viscosity).

\section{Acknowledgment}

15 We would like to express our special thanks of gratitude to Dr. Christine Long from Academic Language and Learning Service at the Queensland University of Technology who helped us doing this study with his valuable comments.

\section{References}

Andersen, M. S., and Acworth, R. (2009). Stream-aquifer interactions in the Maules Creek catchment, Namoi Valley, New South Wales, Australia. Hydrogeology Journal, 17(8), 2005-2021.

Anderson, M. P. (2005). Heat as a Ground Water Tracer. Groundwater, 43(6), 951-968. doi:10.1111/j.17456584.2005.00052.x

Arnoux, M., Gibert-Brunet, E., Barbecot, F., Guillon, S., Gibson, J., and Noret, A. (2017). Interactions between groundwater and seasonally ice-covered lakes: using water stable isotopes and radon-222 multi-layer mass balance models. Hydrological Processes. doi:10.1002/hyp.11206

Baskaran, S., Brodie, R., Ransley, T., and Baker, P. (2009). Time-series measurements of stream and sediment temperature for understanding river-groundwater interactions: Border Rivers and Lower Richmond catchments, Australia. Australian Journal of Earth Sciences, 56(1), 21-30.

Ben-zvi-Assarf, O., and Orion, N. (2005). A study of junior high students' perceptions of the water cycle. 
Hydrol. Earth Syst. Sci. Discuss., https://doi.org/10.5194/hess-2017-374

Manuscript under review for journal Hydrol. Earth Syst. Sci.

Discussion started: 3 July 2017

(c) Author(s) 2017. CC BY 4.0 License.
Hydrology and

Earth System

Sciences

Discussions

Boulton, A. J., Findlay, S., Marmonier, P., Stanley, E. H., and Valett, H. M. (1998). The functional significance of the hyporheic zone in streams and rivers. Annual Review of Ecology and Systematics, 29(1), 59-81.

Briody, A. C., Cardenas, M. B., Shuai, P., Knappett, P. S. K., and Bennett, P. C. (2016). Groundwater flow, nutrient, and stable isotope dynamics in the parafluvial-hyporheic zone of the regulated Lower Colorado River

(Texas, USA) over the course of a small flood. Hydrogeology Journal, 24(4), 923-935. doi:10.1007/s10040-

016-1365-3

Brodie, R., Sundaram, B., Tottenham, R., Hostetler, S., and Ransley, T. (2007). An overview of tools for assessing groundwater-surface water connectivity. Bureau of Rural Sciences, Canberra, Australia, 131. Buffington, J. M., and Tonina, D. (2009). Hyporheic exchange in mountain rivers II: effects of channel morphology on mechanics, scales, and rates of exchange. Geography Compass, 3(3), 1038-1062.

Burnett, W. C., Peterson, R. N., Santos, I. R., and Hicks, R. W. (2010). Use of automated radon measurements for rapid assessment of groundwater flow into Florida streams. Journal of Hydrology, 380(3-4), 298-304. doi:10.1016/j.jhydrol.2009.11.005

Cardenas, M. B., Wilson, J., and Zlotnik, V. A. (2004). Impact of heterogeneity, bed forms, and stream curvature on subchannel hyporheic exchange. Water Resources Research, 40(8).

Cartwright, I., Hofmann, H., Sirianos, M. A., Weaver, T. R., and Simmons, C. T. (2011). Geochemical and 222 Rn constraints on baseflow to the Murray River, Australia, and timescales for the decay of low-salinity groundwater lenses. Journal of Hydrology, 405(3), 333-343.

Cleceri, L., Greenberg, A., and Eaton, A. (1998). Standard methods for the examination of water and wastewater. American Public Health Association, American Water Works Association, and Water Environment Association, Washington, DC, USA.

Constantz, J. (1998). Interaction between stream temperature, streamflow, and groundwater exchanges in alpine streams. Water Resources Research, 34(7), 1609-1615. doi:10.1029/98WR00998

Constantz, J., Thomas, C. L., and Zellweger, G. (1994). Influence of diurnal variations in stream temperature on streamflow loss and groundwater recharge. Water Resources Research, 30(12), 3253-3264.

doi:10.1029/94WR01968

Constantz, J., Tyler, S. W., and Kwicklis, E. (2003). Temperature-profile methods for estimating percolation rates in arid environments. Vadose Zone Journal, 2(1), 12-24.

Cook, P. G. (2013). Estimating groundwater discharge to rivers from river chemistry surveys. Hydrological 
Hydrol. Earth Syst. Sci. Discuss., https://doi.org/10.5194/hess-2017-374

Cox, M. H., Su, G. W., and Constantz, J. (2007). Heat, chloride, and specific conductance as ground water tracers near streams. Ground Water, 45(2), 187-195.

Craig, H. (1961). Isotopic variations in meteoric waters. Science, 133(3465), 1702-1703.

Cranswick, R. H., Cook, P. G., and Lamontagne, S. (2014). Hyporheic zone exchange fluxes and residence

times inferred from riverbed temperature and radon data. Journal of Hydrology, 519, 1870-1881.

doi:10.1016/j.jhydrol.2014.09.059

Daughney, C., and Reeves, R. (2006). Analysis of temporal trends in New Zealand's groundwater quality based on data from the National Groundwater Monitoring Programme. Journal of Hydrology (New Zealand), 45(1), 41.

Dixon-Jain, P. (2012). Groundwater-surface water interactions: implications for nutrient transport to tropical rivers.

Dodangeh, E., Soltani, S., Sarhadi, A., and Shiau, J. T. (2014). Application of L-moments and Bayesian inference for low-flow regionalization in Sefidroud basin, Iran. Hydrological Processes, 28(4), 1663-1676.

Ellins, K. K., Roman-Mas, A., and Lee, R. (1990). Using 222Rn to examine groundwater/surface discharge interaction in the Rio Grande de Manati, Puerto Rico. Journal of Hydrology, 115(1-4), 319-341.

Engelhardt, I., Piepenbrink, M., Trauth, N., Stadler, S., Kludt, C., Schulz, M., . . Ternes, T. A. (2011). Comparison of tracer methods to quantify hydrodynamic exchange within the hyporheic zone. Journal of Hydrology, 400(1-2), 255-266. doi:10.1016/j.jhydrol.2011.01.033

Findlay, S. (1995). Importance of surface-subsurface exchange in stream ecosystems: The hyporheic zone.

Limnology and oceanography, 40(1), 159-164.

Fleckenstein, J. H., Krause, S., Hannah, D. M., and Boano, F. (2010). Groundwater-surface water interactions: New methods and models to improve understanding of processes and dynamics. Advances in Water Resources, 33(11), 1291-1295. doi:https://doi.org/10.1016/j.advwatres.2010.09.011

Forsmark, S.-S. (2007). Hydrochemistry in surface water and shallow groundwater.

Fox, A., Laube, G., Schmidt, C., Fleckenstein, J., and Arnon, S. (2016). The effect of losing and gaining flow conditions on hyporheic exchange in heterogeneous streambeds. Water Resources Research, 52(9), 7460-7477. Gariglio, F. P., Tonina, D., and Luce, C. H. (2013). Spatiotemporal variability of hyporheic exchange through a pool-riffle-pool sequence. Water Resources Research, 49(11), 7185-7204. doi:10.1002/wrcr.20419

Gat, J. (1987). Variability (in time) of the isotopic composition of precipitation: consequences regarding the isotopic composition of hydrologic systems Isotope techniques in water resources development. 
Genereux, D. P., Hemond, H. F., and Mulholland, P. J. (1993). Use of radon-222 and calcium as tracers in a three-end-member mixing model for streamflow generation on the West Fork of Walker Branch Watershed. Journal of Hydrology, 142(1), 167-211.

Gu, L., Zhang, S., He, L., Chen, D., Blanckaert, K., Ottevanger, W., and Zhang, Y. (2016). Modeling Flow

Pattern and Evolution of Meandering Channels with a Nonlinear Model. Water, 8(10), 418.

Guggenmos, M., Daughney, C., Jackson, B., and Morgenstern, U. (2011). Regional-scale identification of groundwater-surface water interaction using hydrochemistry and multivariate statistical methods, Wairarapa Valley, New Zealand. Hydrology and Earth System Sciences, 15(11), 3383.

Güler, C., and Thyne, G. D. (2004). Delineation of hydrochemical facies distribution in a regional groundwater system by means of fuzzy c-means clustering. Water Resources Research, 40(12).

Güler, C., Thyne, G. D., McCray, J. E., and Turner, K. A. (2002). Evaluation of graphical and multivariate statistical methods for classification of water chemistry data. Hydrogeology Journal, 10(4), 455-474.

Harvey, F. E., Lee, D. R., Rudolph, D. L., and Frape, S. K. (1997). Locating groundwater discharge in large lakes using bottom sediment electrical conductivity mapping. Water Resources Research, 33(11), 2609-2615.

Hatch, C. E., Fisher, A. T., Revenaugh, J. S., Constantz, J., and Ruehl, C. (2006). Quantifying surface watergroundwater interactions using time series analysis of streambed thermal records: Method development. Water Resources Research, 42(10).

Hermans, T., Wildemeersch, S., Jamin, P., Orban, P., Brouyère, S., Dassargues, A., and Nguyen, F. (2015). Quantitative temperature monitoring of a heat tracing experiment using cross-borehole ERT. Geothermics, 53, 14-26. doi:http://dx.doi.org/10.1016/j.geothermics.2014.03.013

Hester, E. T., Cardenas, M. B., Haggerty, R., and Apte, S. V. (2017). The importance and challenge of hyporheic mixing. Water Resources Research.

Hyun, Y., Kim, H., Lee, S.-S., and Lee, K.-K. (2011). Characterizing streambed water fluxes using temperature and head data on multiple spatial scales in Munsan stream, South Korea. Journal of Hydrology, 402(3-4), 377387. doi:10.1016/j.jhydrol.2011.03.032

Kalbus, E., Reinstorf, F., and Schirmer, M. (2006). Measuring methods for groundwater, surface water and their interactions: a review. Hydrology and Earth System Sciences Discussions, 3(4), 1809-1850.

Keery, J., Binley, A., Crook, N., and Smith, J. W. (2007). Temporal and spatial variability of groundwatersurface water fluxes: development and application of an analytical method using temperature time series. 
Kendall, C., and McDonnell, J. J. (2012). Isotope tracers in catchment hydrology: Elsevier.

King, A., Raiber, M., and Cox, M. E. (2014). Multivariate statistical analysis of hydrochemical data to assess alluvial aquifer-stream connectivity during drought and flood: Cressbrook Creek, southeast Queensland, Australia. Hydrogeology Journal, 22(2), 481-500.

5 Kokot, S., Grigg, M., Panayiotou, H., and Phuong, T. D. (1998). Data interpretation by some common chemometrics methods. Electroanalysis, 10(16), 1081-1088.

Lamontagne, S., and Cook, P. G. (2007). Estimation of hyporheic water residence time in situ using 222Rn disequilibrium. Limnol. Oceanogr.: Methods, 5, 407-416.

Lapworth, D. J., MacDonald, A. M., Krishan, G., Rao, M. S., Gooddy, D. C., and Darling, W. G. (2015).

Groundwater recharge and age-depth profiles of intensively exploited groundwater resources in northwest India.

Geophysical Research Letters, 42(18), 7554-7562. doi:10.1002/2015GL065798

Lee, D. R. (1977). A device for measuring seepage flux in lakes and estuaries. Limnology and oceanography, $22(1), 140-147$.

Lee, R. W., and Hollyday, E. F. (1993). Use of radon measurements in Carters Creek, Maury County,

15 Tennessee, to determine location and magnitude of ground-water seepage. Field Studies of Radon in Rocks, Soils, and Water, 237-242.

Liñán Baena, C., Andreo, B., Mudry, J., and Carrasco Cantos, F. (2008). Groundwater temperature and electrical conductivity as tools to characterize flow patterns in carbonate aquifers: The Sierra de las Nieves karst aquifer, southern Spain. Hydrogeology Journal, 17(4), 843-853. doi:10.1007/s10040-008-0395-x Malard, F., Tockner, K., DOLE-OLIVIER, M. J., and Ward, J. (2002). A landscape perspective of surfacesubsurface hydrological exchanges in river corridors. Freshwater Biology, 47(4), 621-640.

McLean, R., Oswood, M. W., Irons, J. G., and McDowell, W. H. (1999). The effect of permafrost on stream biogeochemistry: a case study of two streams in the Alaskan (USA) taiga. Biogeochemistry, 47(3), 239-267. Naranjo, R. C., Pohll, G., Niswonger, R. G., Stone, M., and McKay, A. (2013). Using heat as a tracer to estimate spatially distributed mean residence times in the hyporheic zone of a riffle-pool sequence. Water Resources Research, 49(6), 3697-3711. doi:10.1002/wrcr.20306

Oyarzún, R., Barrera, F., Salazar, P., Maturana, H., Oyarzún, J., Aguirre, E., . . Kretschmer, N. (2014). Multimethod assessment of connectivity between surface water and shallow groundwater: the case of Limarí River basin, north-central Chile. Hydrogeology Journal, 22(8), 1857-1873. doi:10.1007/s10040-014-1170-9 
Payne, B. R. (1970). Water balance of Lake Chala and its relation to groundwater from tritium and stable isotope data. Journal of Hydrology, 11(1), 47-58.

Peterson, R. N., Santos, I. R., and Burnett, W. C. (2010). Evaluating groundwater discharge to tidal rivers based on a Rn-222 time-series approach. Estuarine, Coastal and Shelf Science, 86(2), 165-178.

5 doi:10.1016/j.ecss.2009.10.022

Piper, A. M. (1944). A graphic procedure in the geochemical interpretation of water-analyses. Eos, Transactions American Geophysical Union, 25(6), 914-928.

Raiber, M., White, P. A., Daughney, C. J., Tschritter, C., Davidson, P., and Bainbridge, S. E. (2012). Threedimensional geological modelling and multivariate statistical analysis of water chemistry data to analyse and visualise aquifer structure and groundwater composition in the Wairau Plain, Marlborough District, New Zealand. Journal of Hydrology, 436, 13-34.

Ronan, A. D., Prudic, D. E., Thodal, C. E., and Constantz, J. (1998). Field study and simulation of diurnal temperature effects on infiltration and variably saturated flow beneath an ephemeral stream. Water Resources Research, 34(9), 2137-2153. doi:10.1029/98WR01572

Rowden, R. (2008). Groundwater Quality Evaluation of the Dakota Aquifer in Northwest Iowa.

Rugel, K., Golladay, S. W., Jackson, C. R., and Rasmussen, T. C. (2016). Delineating groundwater/surface water interaction in a karst watershed: Lower Flint River Basin, southwestern Georgia, USA. Journal of Hydrology: Regional Studies, 5, 1-19. doi:https://doi.org/10.1016/j.ejrh.2015.11.011

Santucci, L., Carol, E., Borzi, G., and García, M. (2017). Hydrogeochemical and isotopic signature of surface and groundwater in a highly industrialized sector of the Rio de la Plata coastal plain (Argentina). Marine Pollution Bulletin.

Shalmani, M., Khorasani, A., Bieranvand, N., Majdabadi, A., Shirzadi, A., and Asl, G. (2016). Use of Isotopic and Related Techniques for Increasing Water Conservation and Yield Production in a Part of Anzali Wetland in the Islamic Republic of Iran. IAEA TECDOC SERIES, 6.

Sharifimanesh, H., Faghhirad, S., and Amiryazdani, F. (2015). Twenty Years River Training Works In GhezelOwzan River in Iran. Paper presented at the 14th National Conference on HYDRAULIC, Zahedan, Iran. Silliman, S. E., and Booth, D. F. (1993). Analysis of time-series measurements of sediment temperature for identification of gaining vs. losing portions of Juday Creek, Indiana. Journal of Hydrology, 146, 131-148. doi:http://dx.doi.org/10.1016/0022-1694(93)90273-C 
Smith, J., Bonell, M., Gibert, J., McDowell, W., Sudicky, E., Turner, J., and Harris, R. (2008). Groundwatersurface water interactions, nutrient fluxes and ecological response in river corridors: translating science into effective environmental management. Hydrological Processes, 22(1), 151-157.

Sokal, R. R., and Rohlf, F. J. (1962). The comparison of dendrograms by objective methods. Taxon, 33-40.

5 Sophocleous, M. (2002). Interactions between groundwater and surface water: the state of the science.

Hydrogeology Journal, 10(1), 52-67.

Stellato, L., Petrella, E., Terrasi, F., Belloni, P., Belli, M., Sansone, U., and Celico, F. (2008). Some limitations in using 222Rn to assess river-groundwater interactions: the case of Castel di Sangro alluvial plain (central Italy). Hydrogeology Journal, 16(4), 701-712.

10 Stichler, W., Maoszewski, P., and Moser, H. (1986). Modelling of river water infiltration using oxygen-18 data. Journal of Hydrology, 83(3), 355-365. doi:http://dx.doi.org/10.1016/0022-1694(86)90161-7

Stonestrom, D. A., and Constantz, J. (2003). Heat as a tool for studying the movement of ground water near streams: US Dept. of the Interior, US Geological Survey.

Storey, R. G., Howard, K. W., and Williams, D. D. (2003). Factors controlling riffle-scale hyporheic exchange flows and their seasonal changes in a gaining stream: A three-dimensional groundwater flow model. Water Resources Research, 39(2).

Throckmorton, H. M., Newman, B. D., Heikoop, J. M., Perkins, G. B., Feng, X., Graham, D. E., .. .

Wullschleger, S. D. (2016). Active layer hydrology in an arctic tundra ecosystem: quantifying water sources and cycling using water stable isotopes. Hydrological Processes, 30(26), 4972-4986.

Tonina, D., and Buffington, J. M. (2007). Hyporheic exchange in gravel bed rivers with pool-riffle morphology: Laboratory experiments and three-dimensional modeling. Water Resources Research, 43(1).

Toudeshki, V. H., and Arian, M. (2011). Morphotectonic Analysis in the Ghezel Ozan River Basin, NW Iran. Journal of Geography and Geology, 3(1), 258.

Unland, N. P., Cartwright, I., Andersen, M. S., Rau, G. C., Reed, J., Gilfedder, B. S., . . Hofmann, H. (2013). Investigating the spatio-temporal variability in groundwater and surface water interactions: a multi-technique approach. Hydrology and Earth System Sciences, 17(9), 3437-3453. doi:10.5194/hess-17-3437-2013 Vanplantinga, A. A., Grossman, E. L., and Roark, E. B. (2017). Chemical and Isotopic Tracer Evaluation of Water Mixing and Evaporation in a Dammed Texas River During Drought. River Research and Applications, 33(3), 450-460. doi:10.1002/rra.3080 
Hydrol. Earth Syst. Sci. Discuss., https://doi.org/10.5194/hess-2017-374

Veras, T. B., Cabral, J. J. d. S. P., Paiva, A. L. R. d., Barcellos, R. L., and Santos, L. L. d. (2016). Vertical hydraulic gradient research in hyporheic zone of Beberibe river in Pernambuco State (Brazil). RBRH(AHEAD), $0-0$.

Vinson, D. S., Vengosh, A., Hirschfeld, D., and Dwyer, G. S. (2009). Relationships between radium and radon occurrence and hydrochemistry in fresh groundwater from fractured crystalline rocks, North Carolina (USA).

Chemical Geology, 260(3), 159-171.

Wang, W., Dai, Z., Zhao, Y., Li, J., Duan, L., Wang, Z., and Zhu, L. (2016). A quantitative analysis of hydraulic interaction processes in stream-aquifer systems. Scientific reports, 6 .

Welch, C., Harrington, G. A., and Cook, P. G. (2015). Influence of groundwater hydraulic gradient on bank storage metrics. Groundwater, 53(5), 782-793.

Werner, K., Johansson, P.-O., Brydsten, L., Bosson, E., and Berglund, S. (2007). Recharge and discharge of near-surface groundwater in Forsmark. Comparison of classification methods. Retrieved from Winter, T. C. (1998). Ground water and surface water: a single resource (Vol. 1139): DIANE Publishing Inc. Wondzell, S. M. (2006). Effect of morphology and discharge on hyporheic exchange flows in two small streams in the Cascade Mountains of Oregon, USA. Hydrological Processes, 20(2), 267-287.

Woocay, A., and Walton, J. (2008). Multivariate analyses of water chemistry: surface and ground water interactions. Ground Water, 46(3), 437-449.

Wu, L., Singh, T., Lewandowski, J., Nuetzmann, G., Worman, A., Hannah, D., . . Gomez-Velez, J. (2017). Dynamic Hyporheic Zones: Exploring the Role of Transient Flood Pulses on Bedform-induced Exchange under Gaining and Losing Conditions. Paper presented at the EGU General Assembly Conference Abstracts. Yan, Z., Fadong, L., Jing, L., Qiang, L., and Guangshuai, Z. (2013). Quantitative estimation of groundwater recharge ratio along the riparian of the Yellow River. Water Science and Technology, 68(11), 2427-2433. Yeh, H.-F., Lin, H.-I., Lee, C.-H., Hsu, K.-C., and Wu, C.-S. (2014). Identifying seasonal groundwater recharge using environmental stable isotopes. Water, 6(10), 2849-2861.

25 Yehdeghoa, B., Rozanski, K., Zojer, H., and Stichler, W. (1997). Interaction of dredging lakes with the adjacentgroundwater field: an isotope study. Journal of Hydrology, 192(1-4), 247-270.

Yoneda, M., Inoue, Y., and Takine, N. (1991). Location of groundwater seepage points into a river by measurement of $222 \mathrm{Rn}$ concentration in water using activated charcoal passive collectors. Journal of Hydrology, 124(3), 307-316. 
Hydrol. Earth Syst. Sci. Discuss., https://doi.org/10.5194/hess-2017-374

Zarnetske, J. P., Gooseff, M. N., Bowden, W. B., Greenwald, M. J., Brosten, T. R., Bradford, J. H., and

McNamara, J. P. (2008). Influence of morphology and permafrost dynamics on hyporheic exchange in arctic headwater streams under warming climate conditions. Geophysical Research Letters, 35(2).

Zhang, G., Song, J., Wen, M., Zhang, J., Jiang, W., Wang, L., . . Wang, Y. (2017). Effect of bank curvatures on

5 hyporheic water exchange at meter scale. Hydrology Research, 48(2), 355-369.

Zhu, J., Shu, L., Lu, C., Li, J., Chen, S., Li, S., and Wang, G. (2015). Study of heterogeneous vertical hyporheic flux via streambed temperature at different depths. Proceedings of the International Association of Hydrological

Sciences, 368, 168-173.

10

Table 1: The hydrochemical properties of the water in the study site

\begin{tabular}{|l|l|l|l|l|l|l|l|l|l|l|}
\hline & $\mathrm{pH}$ & $\begin{array}{l}\mathrm{EC} \\
\mu \mathrm{S} / \mathrm{cm}\end{array}$ & $\begin{array}{l}\mathrm{Ca} \\
\mathrm{mg} / 1\end{array}$ & $\begin{array}{l}\mathrm{Mg} \\
\mathrm{mg} / \mathrm{l}\end{array}$ & $\begin{array}{l}\mathrm{K} \\
\mathrm{mg} / \mathrm{l}\end{array}$ & $\begin{array}{l}\mathrm{Na} \\
\mathrm{mg} / 1\end{array}$ & $\begin{array}{l}\mathrm{HCO} 3 \\
\mathrm{mg} / 1\end{array}$ & $\begin{array}{l}\mathrm{Cl} \\
\mathrm{mg} / \mathrm{l}\end{array}$ & $\begin{array}{l}\mathrm{SO} 4 \\
\mathrm{mg} / 1\end{array}$ & $\begin{array}{l}\text { Water } \\
\text { type }\end{array}$ \\
\hline $\mathrm{C} 1$ & 7.8 & 549.44 & 41.3 & 9.5 & 1.2 & 84.0 & 476.3 & 76.2 & 10.2 & NaHCO3 \\
\hline C2 & 7.9 & 526.81 & 39.1 & 9.4 & 0.8 & 82.2 & 487.2 & 75.4 & 9.8 & NaHCO3 \\
\hline C'1 & 8.1 & 400.15 & 93.2 & 5.5 & 1.1 & 35.3 & 375.2 & 30.2 & 15.2 & CaHCO3 \\
\hline C'2 & 8.2 & 467.48 & 97.4 & 5.4 & 0.9 & 36.2 & 376.4 & 33.6 & 15.4 & CaHCO3 \\
\hline
\end{tabular}

Table 2: the isotopic composition of clusters at different depths in dry season

\begin{tabular}{|c|c|c|c|c|c|c|c|c|c|c|}
\hline & \multicolumn{2}{|c|}{$\sigma 180$} & \multicolumn{2}{|c|}{$\sigma \mathrm{D}$} & \multicolumn{2}{|c|}{$\mathrm{EC}$} & d-excess & \multicolumn{3}{|c|}{ P'gw } \\
\hline & $\min$ & $\max$ & $\min$ & $\max$ & $\min$ & $\max$ & \multirow[b]{3}{*}{2.15} & July & August & September \\
\hline c1-20 & -2.96 & -2 & -19.8 & -18.84 & 425.55 & 617.2 & & \multirow[b]{2}{*}{0.58} & \multirow[b]{2}{*}{0.84} & \multirow[b]{2}{*}{0.47} \\
\hline c1-100 & -3.59 & -2.06 & -19.48 & -13.22 & 402.25 & 700.05 & & & & \\
\hline c2-20 & -3.08 & -1.88 & -16.32 & -9.96 & 234.4 & 718.38 & \multirow[b]{2}{*}{3.30} & \multirow[t]{2}{*}{0.72} & \multirow[t]{2}{*}{0.87} & \multirow[t]{2}{*}{0.53} \\
\hline c2-100 & -3.085 & -2.06 & -17.48 & -10.64 & 341.2 & 740.65 & & & & \\
\hline
\end{tabular}

15 Table 3: the water isotopic composition in each cluster during wet season

\begin{tabular}{|l|c|c|c|c|c|l|l|l|l|c|c|}
\hline & \multicolumn{2}{|c|}{$\delta 18 \mathrm{O}$} & \multicolumn{2}{c|}{$\delta 2 \mathrm{H}$} & \multicolumn{2}{c|}{ EC } & \multicolumn{2}{c|}{ d-excess } & \multicolumn{3}{c|}{ P'gw } \\
\hline & $\max$ & $\min$ & $\max$ & $\min$ & $\max$ & $\min$ & & February & March & April & May \\
\hline C'1-20 & -4.04 & -4.90 & -26.91 & -29.04 & 596.912 & 218.365 & 9.3 & 0.13 & 0.08 & 0.07 & 0.04 \\
\hline
\end{tabular}


Hydrol. Earth Syst. Sci. Discuss., https://doi.org/10.5194/hess-2017-374

Manuscript under review for journal Hydrol. Earth Syst. Sci.

Discussion started: 3 July 2017

(c) Author(s) 2017. CC BY 4.0 License.
Hydrology and (c) $\underset{\mathrm{BY}}{(\mathrm{i})}$

\begin{tabular}{|c|c|c|c|c|c|c|c|c|c|c|c|}
\hline $\mathrm{C}^{\prime} 1-100$ & -4.18 & -5.02 & -28.71 & -31.08 & 698.513 & 292.222 & & & & & \\
\hline$C^{\prime} 2-20$ & -4.05 & -5.05 & -24.06 & -31.06 & 663.944 & 278.690 & & & & & \\
\hline$C^{\prime} 2-100$ & -4.18 & -4.77 & -23.81 & -29.09 & 776.955 & 329.450 & 10.2 & 0.12 & 0.06 & 0.03 & 0.05 \\
\hline
\end{tabular}

Table 4: statistical values of temperature recorded time series at the representative points

\begin{tabular}{|c|c|c|c|c|c|c|}
\hline points & month & $\max$ & $\min$ & mean & difference & $\begin{array}{l}\text { Standard } \\
\text { division }\end{array}$ \\
\hline H1-20 & July & 15.86 & 15.00 & 16.10 & 0.86 & 0.21 \\
\hline H1-100 & July & 15.20 & 14.88 & 15.04 & 0.32 & 0.10 \\
\hline $\mathrm{H} 2-20$ & July & 15.48 & 14.87 & 15.22 & 0.61 & 0.16 \\
\hline $\mathrm{H} 2-100$ & July & 15.13 & 14.61 & 14.91 & 0.52 & 0.14 \\
\hline H3-20 & July & 15.61 & 15.05 & 15.34 & 0.56 & 0.17 \\
\hline H3-100 & July & 15.22 & 14.74 & 15.01 & 0.48 & 0.09 \\
\hline H1-20 & August & 16.69 & 15.64 & 16.10 & 1.05 & 0.27 \\
\hline H1-100 & August & 15.84 & 15.15 & 15.48 & 0.69 & 0.19 \\
\hline H8-20 & September & 16.45 & 14.70 & 15.43 & 1.75 & 0.43 \\
\hline H8-100 & September & 15.37 & 14.50 & 14.97 & 0.87 & 0.23 \\
\hline H1-20 & September & 17.83 & 16.04 & 16.79 & 1.79 & 0.44 \\
\hline H1-100 & September & 16.43 & 15.65 & 15.95 & 0.78 & 0.19 \\
\hline H3-20 & September & 18.72 & 16.50 & 17.31 & 2.22 & 0.58 \\
\hline H3-100 & September & 16.52 & 15.54 & 16.09 & 0.98 & 0.26 \\
\hline $\mathrm{S} 1$ & July & 18.64 & 15.06 & 16.88 & 3.58 & 1.04 \\
\hline $\mathrm{S} 1$ & August & 20.79 & 16.12 & 18.67 & 4.66 & 1.15 \\
\hline $\mathrm{S} 1$ & September & 21.50 & 17.32 & 19.55 & 4.18 & 1.10 \\
\hline $\mathrm{S} 2$ & August & 20.81 & 16.68 & 18.86 & 4.13 & 1.07 \\
\hline $\mathrm{S} 2$ & September & 20.99 & 17.39 & 19.19 & 3.60 & 0.95 \\
\hline
\end{tabular}


Hydrol. Earth Syst. Sci. Discuss., https://doi.org/10.5194/hess-2017-374

Manuscript under review for journal Hydrol. Earth Syst. Sci.

Discussion started: 3 July 2017

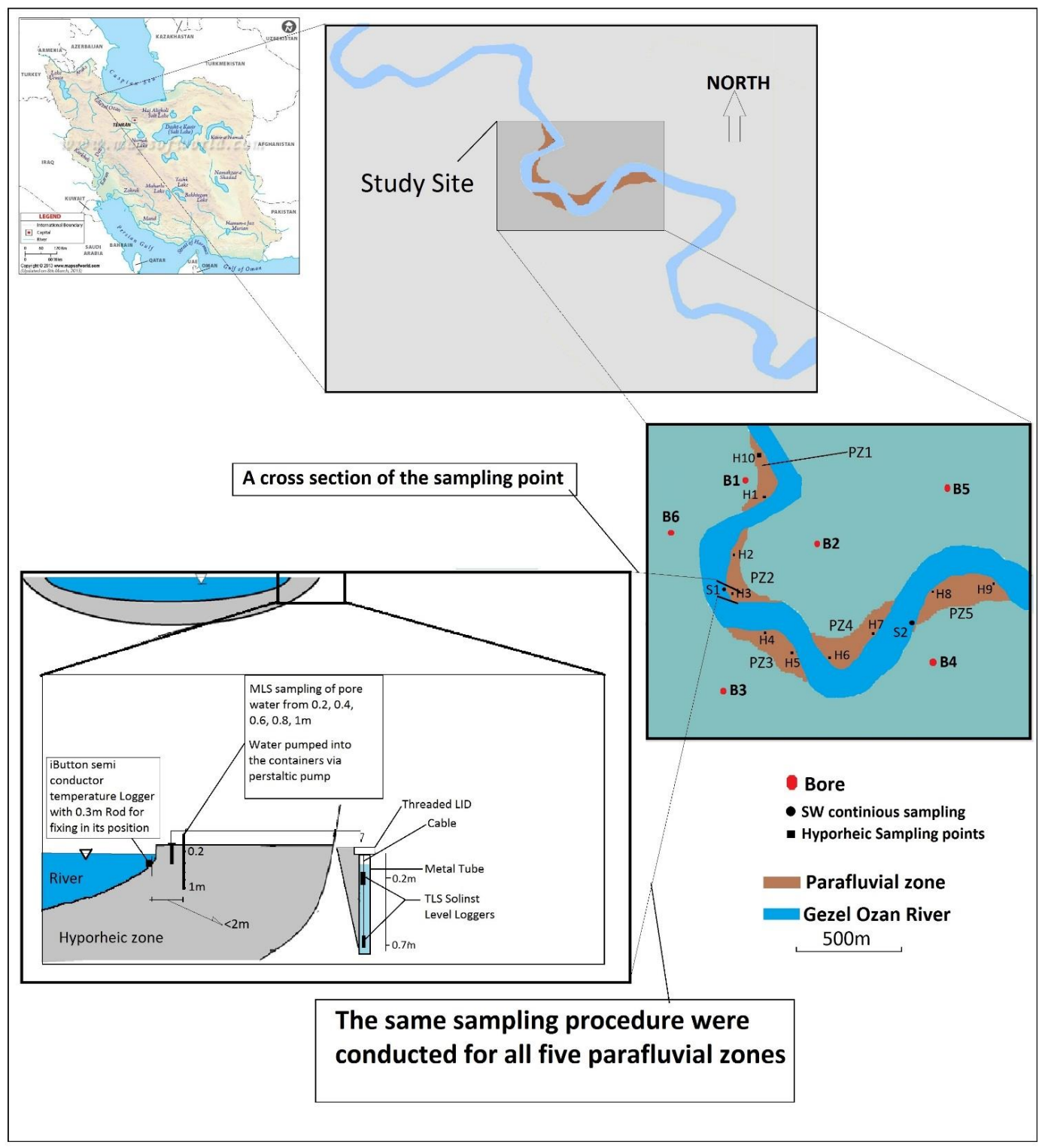

Figure 1: Study site location and schematic diagram of field data sampling procedures. 
Hydrol. Earth Syst. Sci. Discuss., https://doi.org/10.5194/hess-2017-374

Manuscript under review for journal Hydrol. Earth Syst. Sci.

Discussion started: 3 July 2017

(c) Author(s) 2017. CC BY 4.0 License.
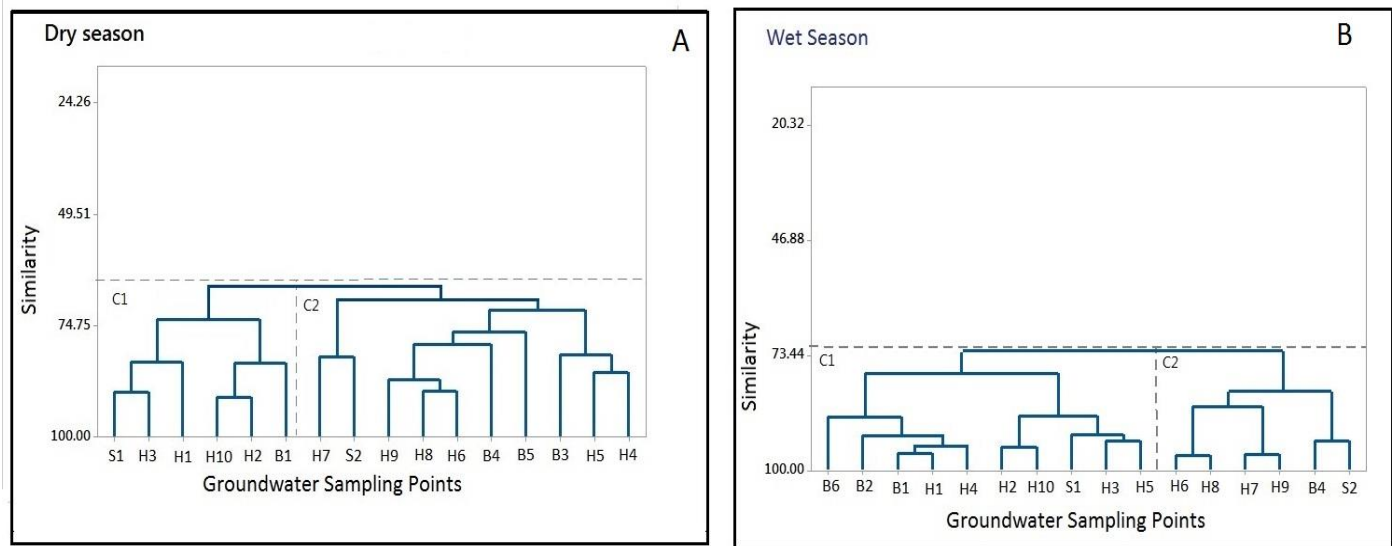

Figure 2: Dendrogram acquired from HCA of SW and parafluvial water data for a) dry season b) wet season.

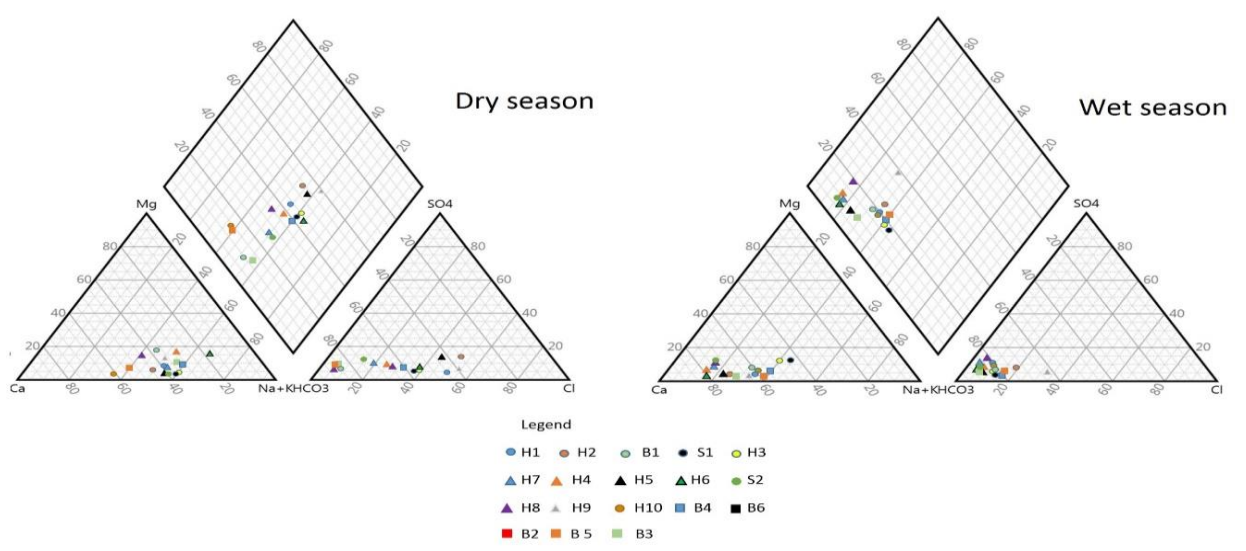

5 Figure 3: Piper plot in wet season and dry season for SW and parafluvial water samples.

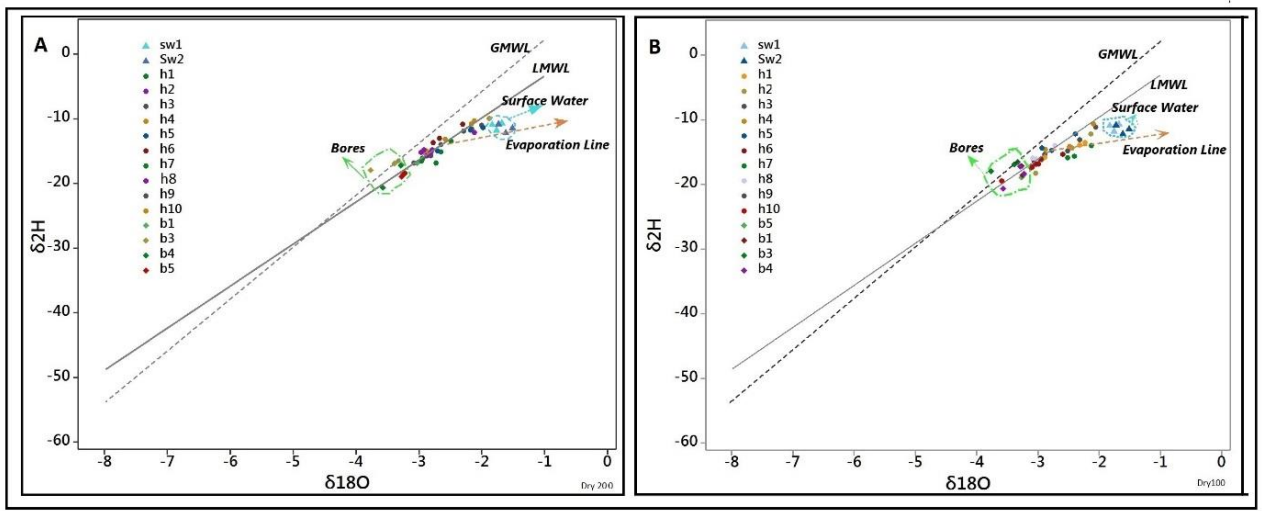


Hydrol. Earth Syst. Sci. Discuss., https://doi.org/10.5194/hess-2017-374

Figure 4: The isotopic composition of sampling point in dry season A) $20 \mathrm{~cm}$ depth B) $100 \mathrm{~cm}$ depth. GMWL: Global Meteoric Water Line, LMWL: Local Meteoric Water Line. Bore water and SW points are highlighted as well as evaporation line.
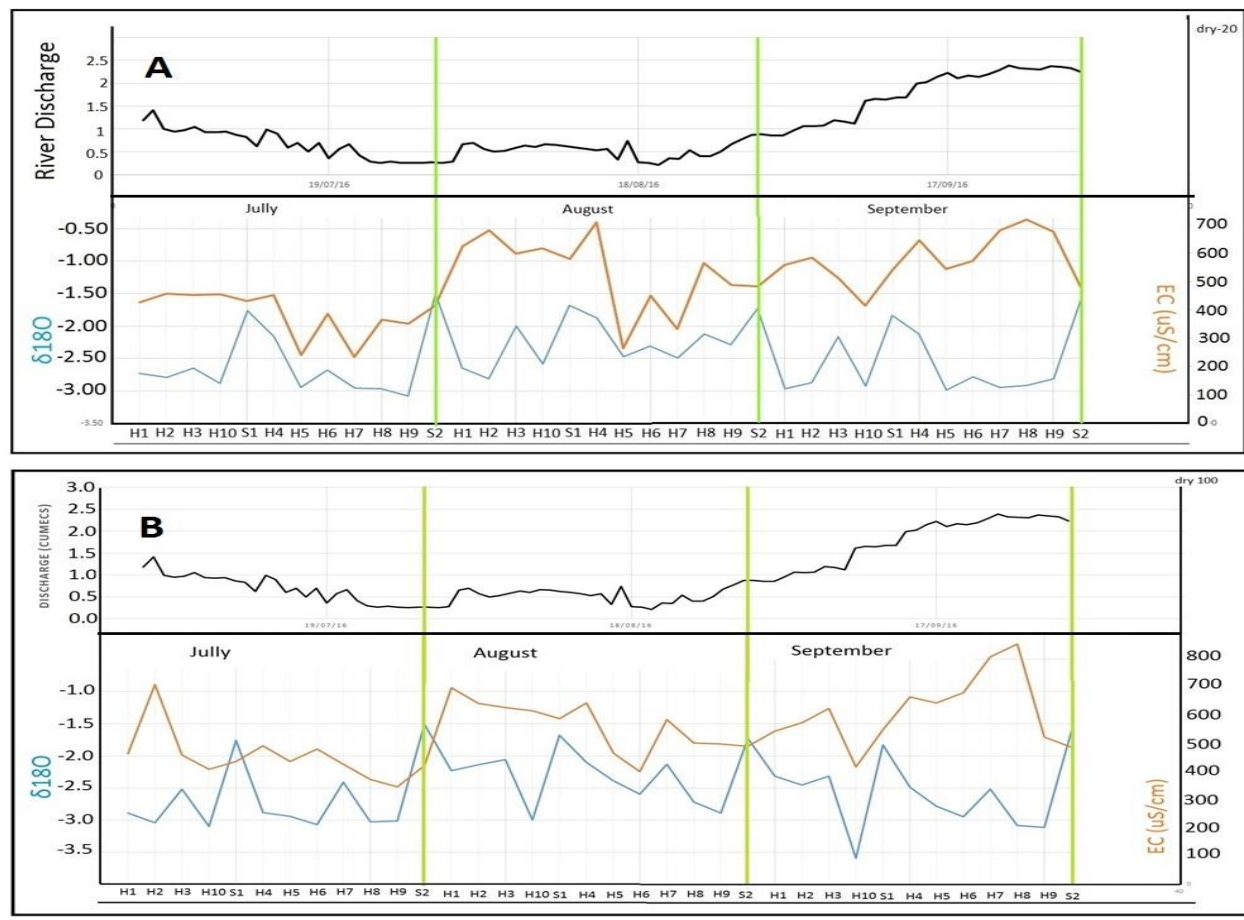

5 Figure 5: Comparison between $\sigma 180$ and $\mathrm{EC}$ at $20 \mathrm{~cm}$ and $100 \mathrm{~cm}$ in dry season $(\mathrm{A}, \mathrm{B})$. each month is separated with green line. 
Hydrol. Earth Syst. Sci. Discuss., https://doi.org/10.5194/hess-2017-374

Manuscript under review for journal Hydrol. Earth Syst. Sci.

Discussion started: 3 July 2017
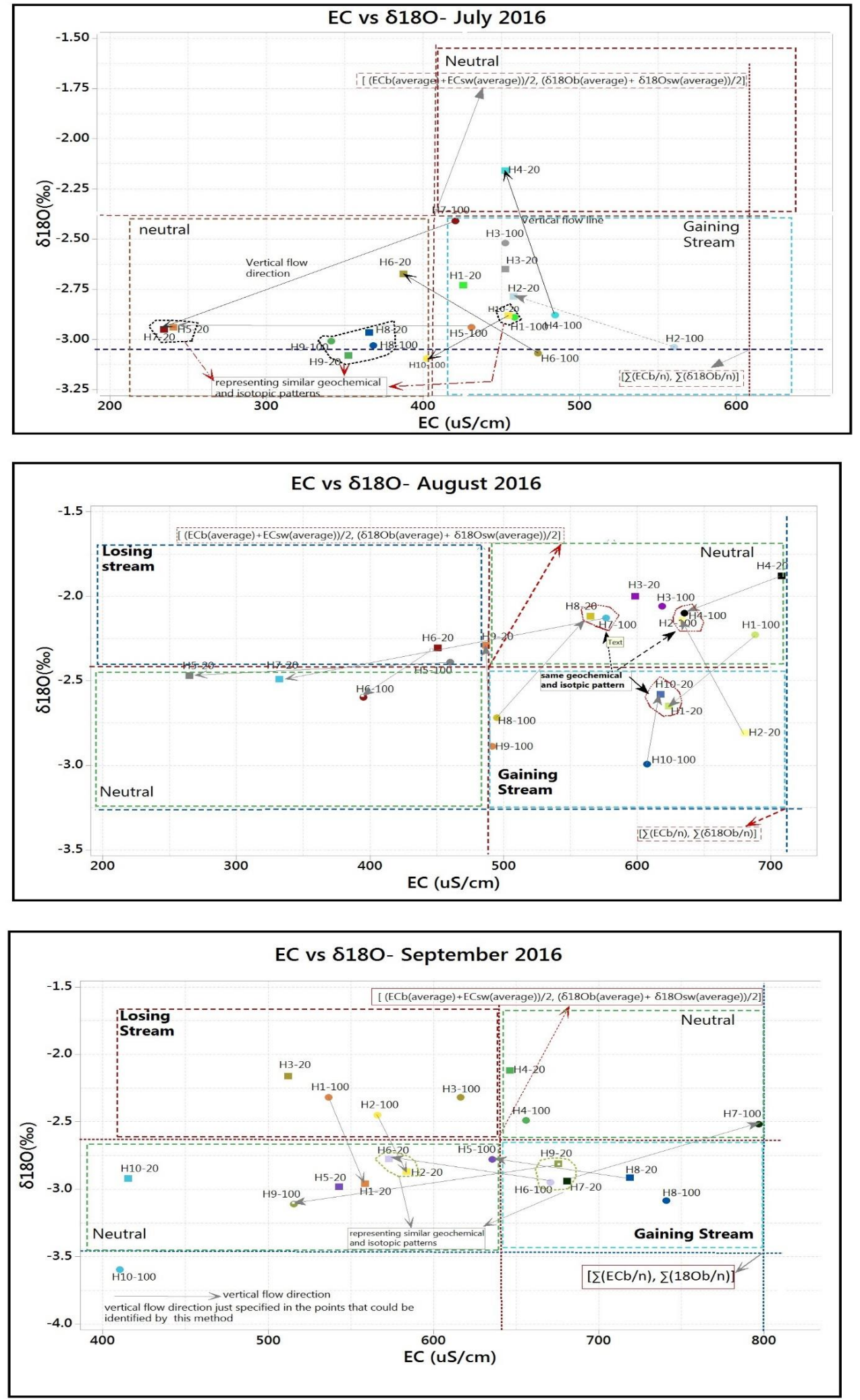
Hydrol. Earth Syst. Sci. Discuss., https://doi.org/10.5194/hess-2017-374

Manuscript under review for journal Hydrol. Earth Syst. Sci.

Discussion started: 3 July 2017

(c) Author(s) 2017. CC BY 4.0 License.

Figure 6: The point comparison of EC and $\sigma 180$ to in-depth delineate the gaining stream (discharge) and losing stream (recharge) in each point as well as vertical flow directions in dry season. The vertical direction which are nor indicated could not been assessed by this method.

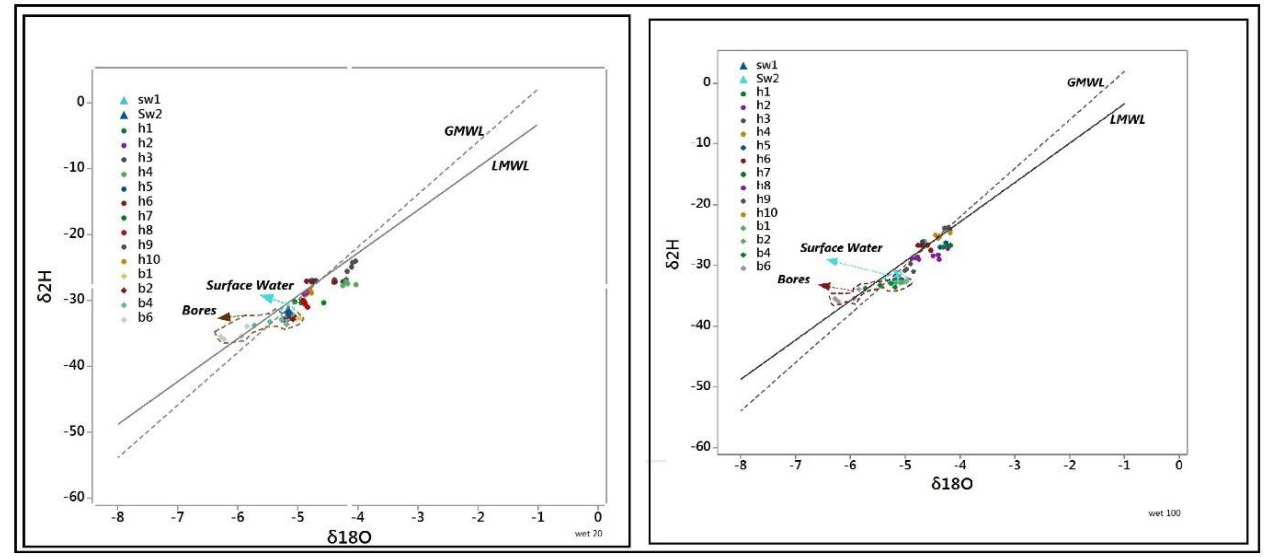

5 Figure 7: The isotopic composition of sampling point in wet season A) $20 \mathrm{~cm}$ depth B) $100 \mathrm{~cm}$ depth. GMWL: Global Meteoric Water Line, LMWL: Local Meteoric Water Line. 
Hydrol. Earth Syst. Sci. Discuss., https://doi.org/10.5194/hess-2017-374
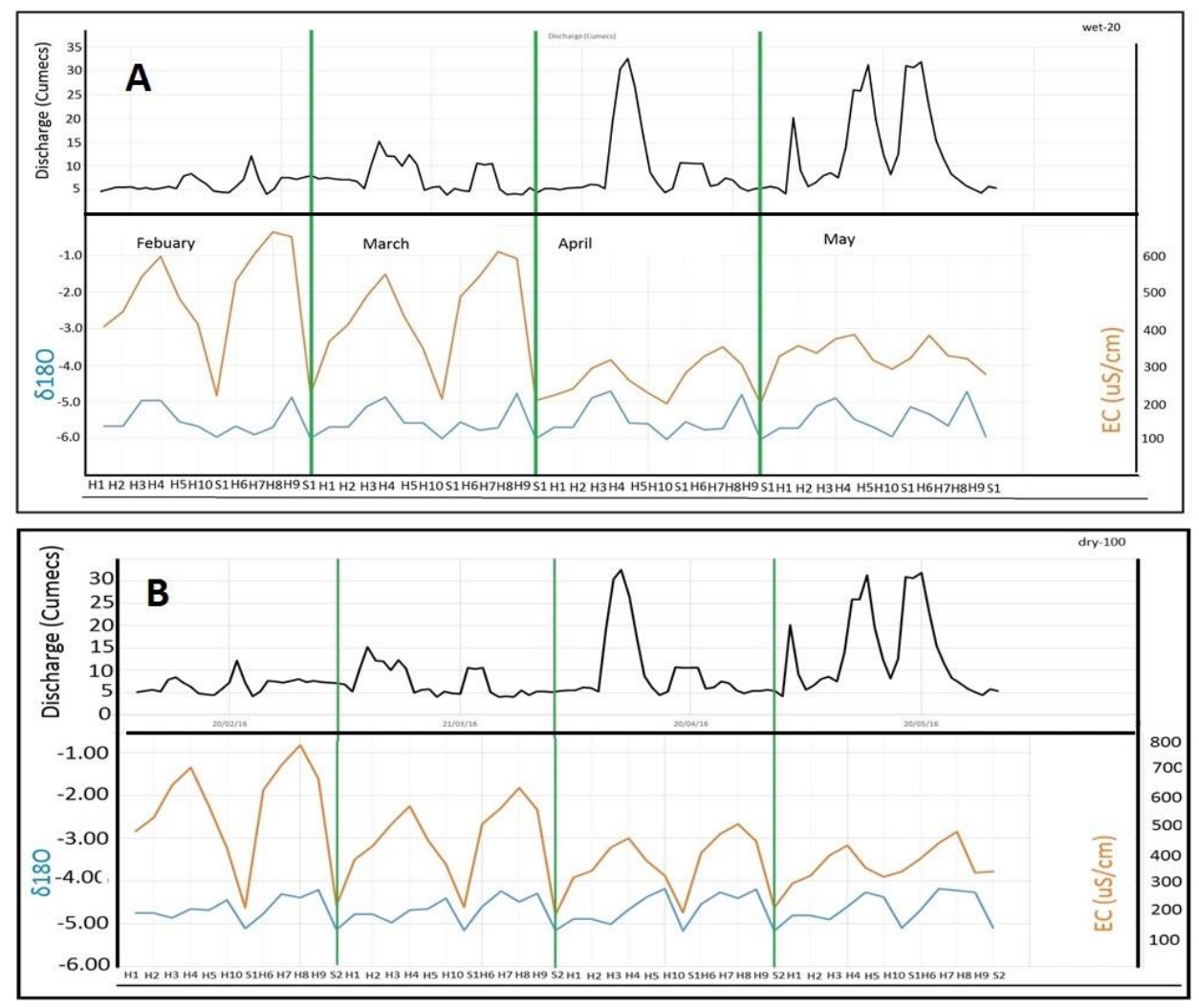

Figure 8: Comparison between $\sigma 180$ and $E C$ at $20 \mathrm{~cm}$ and $100 \mathrm{~cm}$ in dry season $(\mathrm{A}, \mathrm{B})$. Each month is separated by green line. 
Hydrol. Earth Syst. Sci. Discuss., https://doi.org/10.5194/hess-2017-374

Manuscript under review for journal Hydrol. Earth Syst. Sci.

Discussion started: 3 July 2017

(c) Author(s) 2017. CC BY 4.0 License.
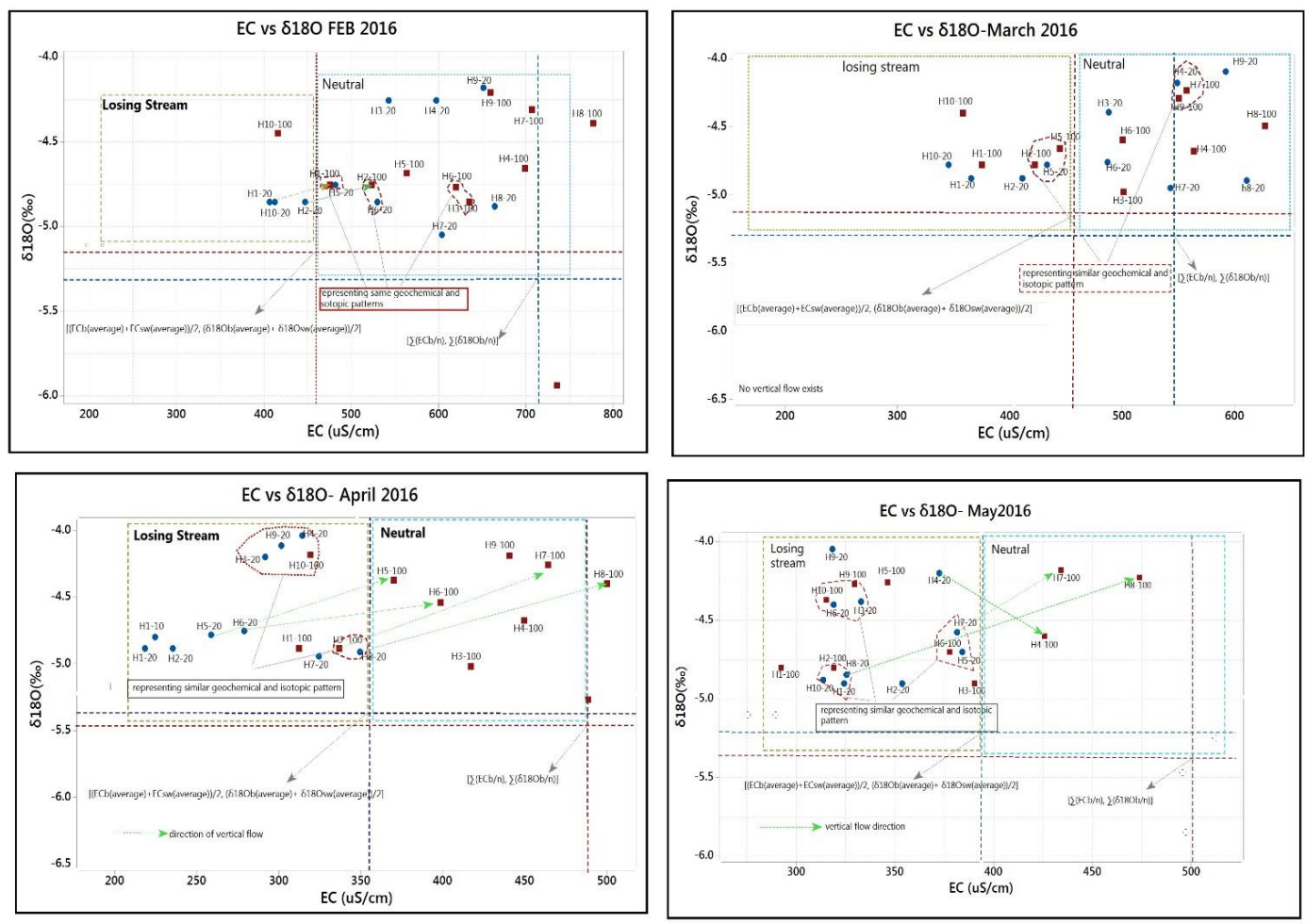

Figure 9: The point comparison of EC and $\sigma 180$ to in-depth delineate the neutral and losing stream (recharge) in each point as well as vertical flow directions in wet season.

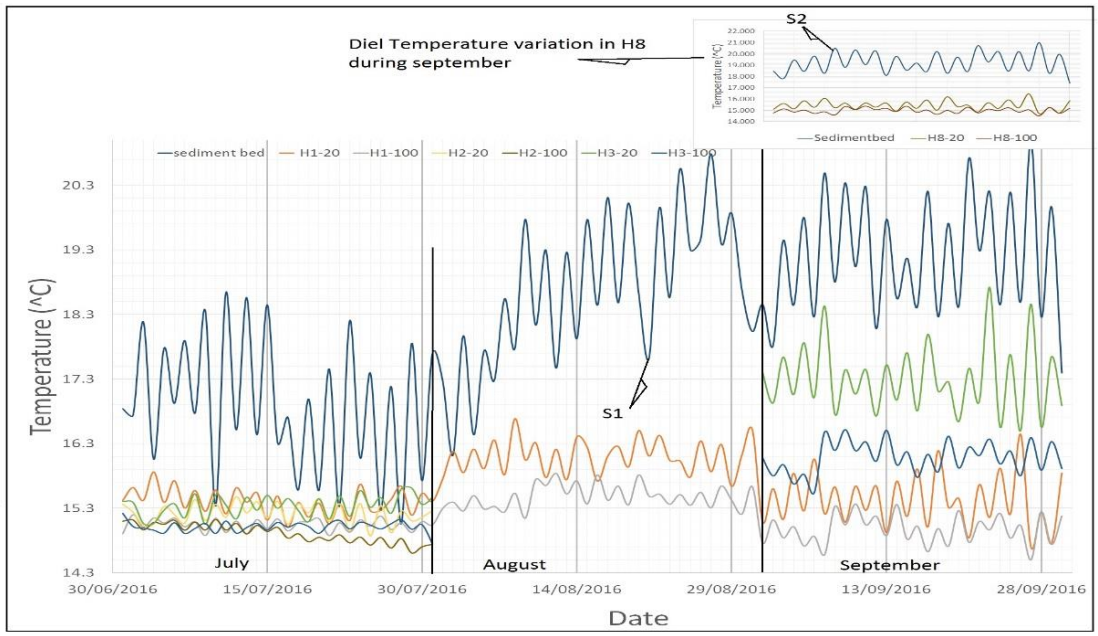

5 Figure 10: Multi-level recorded temperature time series at S1,S2, H1 -Jul, H2- Jul, H3-Jul, H1-Aug, H1Sep, H3- Sep, H8-Sep (top right: $\mathrm{H} 8$ and S2 Are in C2 for more information see section 5.1) during dry season (each month is separated by black line). 
Hydrol. Earth Syst. Sci. Discuss., https://doi.org/10.5194/hess-2017-374

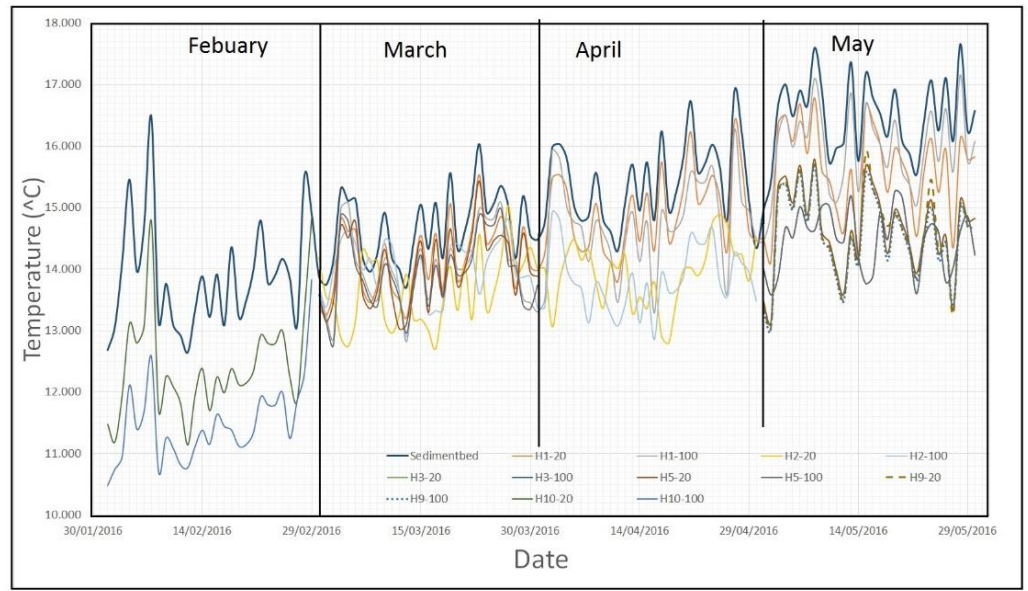

Figure 11: Multi-level recorded temperature time series at S1, H10-Feb,H1-Mar, H2-Mar, H5-Mar, H1Apr, H2-Apr, H1-May, H3-May, H5-May, and H9 May (S2 was damaged on account of heavy run off in $13^{\text {th }}$ of April and the S1 was used instead of S2) (each month is separated with black line).
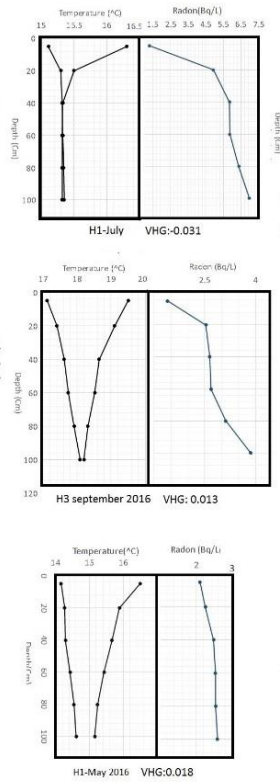
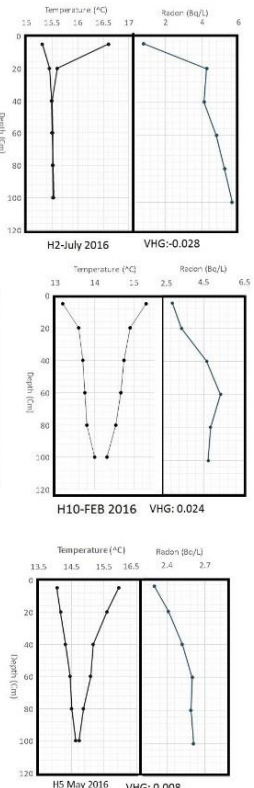
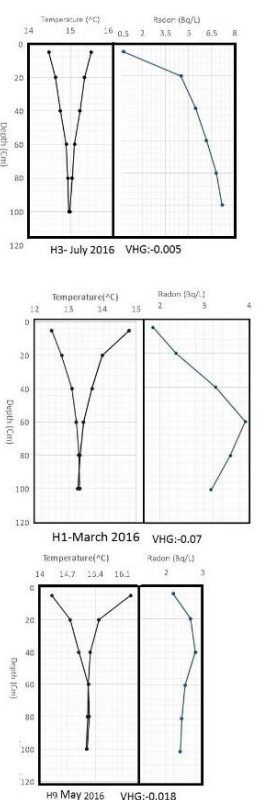

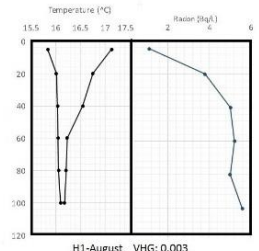

H1-August VHG: 0.003

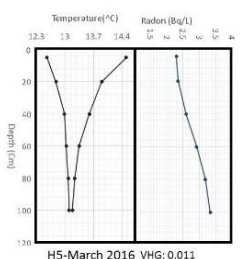

H5-March 2016 VHG: 0.011
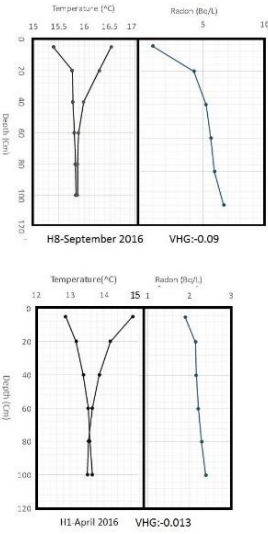

5

Figure 12: Vertical profiles of radon and $24 \mathrm{~h}$ temperature envelopes at representative points. The value VHD refers to the vertical hydraulic gradient $(\mathrm{dh})$ between the river and $100 \mathrm{~cm}$ depth $(+$ is a downward gradient, - is an upward gradient). 